\title{
CELTNIECĪBAS KERAMIKA, KERAMZĪTS UN KERAMISKIE SORBENTI
}

\author{
RUTA ŠVINKA ${ }^{1^{*}}$, VISVALDIS ŠVINKA ${ }^{2}$ \\ 1,2 Silikātu materiālu institūts, Materiālzinātņu un lietišḳās k̦īmijas fakultāte, \\ Rīgas Tehniskā universitāte, Latvija
}

Kopsavilkums. Vēsturiski viena no silikātu tehnologijas katedras pamattēmām vienmēr ir bijusi celtniecības materiālu pētīšana un jaunu materiālu izstrāde. Tie ir gan keramikas materiāli, gan materiāli uz neorganisko javu saistvielu bāzes. Ir analizētas un salīdzinātas šo materiālu īpašîbas: siltuma vadāmība, līdzsvara mitrums, mehāniskās īpašības. Salīdzinātas rūpnieciskos apstākḷos un laboratorijā iegūtu dažādu Latvijas mālu keramikas materiālu īpašības un struktūra. Aprakstīta dažu rūpniecisko atkritumu ietekme uz keramikas materiālu īpašībām. Aprakstīta arī jauna keramikas materiāla keramzīta ražošanas tehnoloǵija - vienas stadijas pan̄ēmiens, kas l̦auj paplašināt keramzìta ražošanai izmantojamo izejvielu bāzi un variēt keramzīta īpašības atkarībā no paredzamā pielietojuma. Pētīta dažādu Latvijas mālu noderība porainu keramisku sorbentu iegūšanai, par poru veidotājiem izmantojot organiskas dabas ražošanas atkritumus. Analizēta keramikas virsmas apstrāde, piemēram, apstarošana ar paātrinātajiem elektroniem un nanodaḷinu pārklājumi, keramikas granulu sorbcijas spējas palielināšanai un noderība fotokatalītiskai organisku piesārṇotāju sadalīšanai.

Atslēgas vārdi - poraina celtniecības keramika, keramzīts, līdzsvara mitrums, siltuma izolācija, keramikas granulas, sorbenti.

\section{Celtniecības keramika}

Ir salīdzinātas dažu celtniecībā plaši izmantotu būvmateriālu (māla ķiegeḷu, Keraterm bloku, silikātķieǵeḷu, gāzbetona, keramzītbetona un betona) ūdens uzsūkšanas kinētika un līdzsvara mitrums ar ūdens tvaikiem piesātinātā atmosfērā. Salīdzināta arī dažu sausu un līdzsvara mitruma stāvoklī esošu rūpniecisko materiālu siltuma vadāmība. Salīdzināšanai ar pussausās presēšanas paṇēmienu no dažādiem Latvijas

* Korespondējošais autors. E-pasts: ruta.svinka@rtu.lv 
māliem (devona Liepas gaišie un sarkanie; kvartāra Apriķu, Lielauces, Usmas, Līvānu, Kalnciema, Brocēnu) izgatavoti paraugi, kas apdedzināti $1000{ }^{\circ} \mathrm{C}$ temperatūrā, un tiem arī noteiktas minētās īpašības. Rezultātu analīzei izmantota rūpnieciskos un laboratorijas apstākḷos iegūto materiālu porainība un poru izmēru sadalījums (noteikšanas metode - dzīvsudraba porozimetrija, porozimetrs Autopore IV, Erlangenas-Nirnbergas universitāte, Vācija), izvērtēta pētīto materiālu izmantošanas lietderība dzīvojamo telpu celtniecībai [1].

Ūdens uzsūkšanas kinētika ir līdzīga visiem laboratorijas apstāklos iegūtiem keramikas paraugiem - intensīva ūdens uzsūkšana notiek pirmajās 15-20 min. Ūdens uzsūkšanas spēja kvartāra māliem ir ievērojami lielāka, tā ir $0,22-0,32 \mathrm{~g} \cdot \mathrm{cm}^{-3}$, atkarībā no mālu atradnes. Salīdzinoši devona mālu apdedzināto paraugu ūdens uzsūkšanas spēja ir 0,12-0,15 $\mathrm{g} \cdot \mathrm{cm}^{-3}$. Līdzsvara mitrums piesātināta tvaika atmosfērā ir atkarīgs no vides temperatūras, t. i., paaugstinoties eksperimenta temperatūrai, līdzsvara mitrums palielinās (1. att.). Līdzsvara mitruma vērtība l̦auj novērtēt arī nepieciešamo apdedzināšanas temperatūru konkrētās atradnes māliem. No iegūtajiem rezultātiem redzams, ka apdedzināšanas temperatūra $1000{ }^{\circ} \mathrm{C}$ ir pietiekoša Lielauces, Līvānu un Liepas atradnes māliem, bet Apriksu, Usmas un Kalnciema mālu keramikai, spriežot pēc līdzsvara mitruma, nepieciešama augstāka apdedzināšanas temperatūra.

Komerciāliem celtniecības materiāliem noteiktas tās pašas īpašības, kas l̦auj salīdzināt šos materiālus no izmantošanas viedokḷa. Visus pētītos komerciālos materiālus var iedalīt divās grupās: keramiskie sienu celtniecības materiāli un betona tipa sienu celtniecības materiāli. Šo abu grupu materiālu īpašỉbas attiecībā uz ūdens uzsūkšanu un līdzsvara mitrumu ievērojami atšksiras. No Līvānu māliem ražoto māla k,ieǵeḷu,

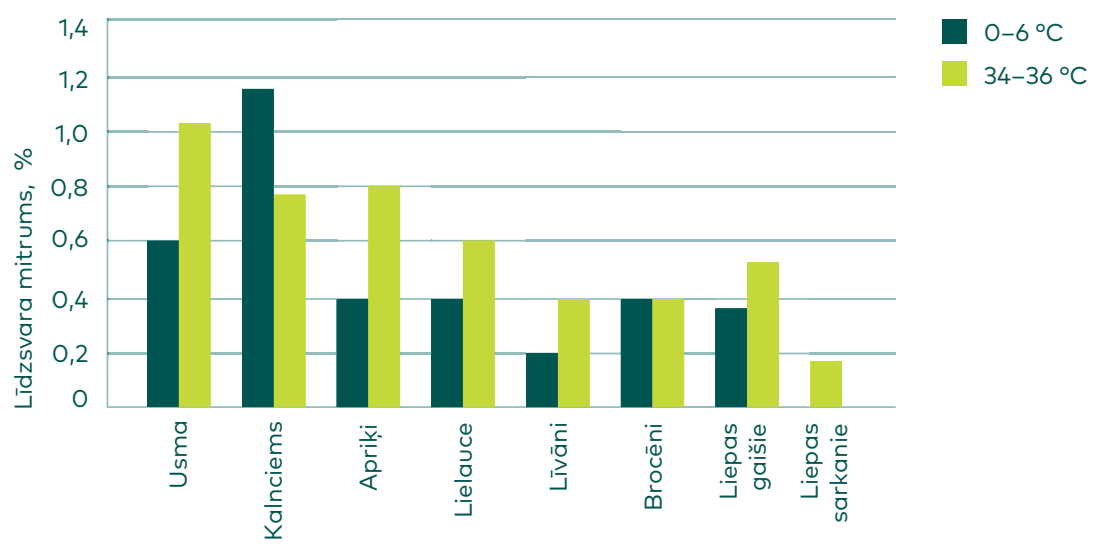

1. att. Līdzsvara mitrums $1000{ }^{\circ} \mathrm{C}$ temperatūrā apdedzinātiem dažādu Latvijas mālu keramikas paraugiem. 
Keraterm bloku un laboratorijā $1000^{\circ} \mathrm{C}$ temperatūrā apdedzināto keramikas paraugu ūdens uzsūkšanas kinētikas rezultāti ir līdzīgi - strauja ūdens uzsūkšana notiek pirmo 15-20 min laikā, un pēc tam lēns process turpinās līdz 1,5 h. Līdzsvara mitrums abiem komerciālajiem keramikas materiāliem, jo sevišķi ksieǵeḷiem, ir zems (2. att.). Līdzsvara mitrums šajos keramikas materiālos ir atkarīgs arī no poru izmēru sadalījuma tajos - jo mazāks ir poru izmērs, jo mazāks ir līdzsvara mitrums. Dažādiem betona grupas materiāliem ūdens uzsūkšana notiek l̦oti strauji pirmo 5 min laikā, bet pēc tam vienmērīgi turpinās nākošās 3 dienas. Vislielākā ūdens uzsūkšanas spēja ir gāzbetonam $-0,28 \mathrm{~g} \cdot \mathrm{cm}^{-3}$. Līdzsvara mitrums šiem materiāliem ir ievērojami lielāks nekā keramikas materiāliem (2. att.), un tas ir atkarīgs no materiāla tilpuma masas. Gāzbetona tilpuma masa ir $0,86 \mathrm{~g} \cdot \mathrm{cm}^{-3}$, bet līdzsvara mitrums $34-36{ }^{\circ} \mathrm{C}$ temperatūrā sasniedz 7,5\%. Savukārt smagā betona tilpuma masa ir $2,11 \mathrm{~g} \cdot \mathrm{cm}^{-3}$, bet līdzsvara mitrums šajā temperatūrā ir 3,4 \%. Līdzsvara mitrums $0-6{ }^{\circ} \mathrm{C}$ temperatūrā ir ievērojami zemāks.

Konstatēts, ka materiālu siltumu izolējošãs īpašības un līdzsvara mitrums ir atkarīgi ne vien no materiāla porainības un poru izmēru sadalījuma, bet arī no kristāliskajām fāzēm, kuras veidojas materiāla iegūšanas procesā. Keramikas materiāliem ir priekšrocības dzīvojamo telpu būvē.

Silikātu keramikas materiālos, kas iegūti no māla izejvielām, poras ir raksturīgs, neiztrūkstošs struktūras elements. Poru daudzums, izvietojums, izmēri un forma ietekmē keramikas īpašības un paver iespēju mērkstiecīgi ietekmēt un iegūt silikātu keramikas materiālus ar vēlamām īpašībām un funkcionālu daudzveidību. Iespēja regulēt keramikas materiālu poru struktūru nodrošina labas materiālu siltuma izolācijas īpašības, atmosfēras un sala izturību, vienlaicīgi saglabājot pietiekoši labas mehāniskās īpašības. Jau agrāk konstatēts, ka celtniecības keramikas

8
6
4
2
0

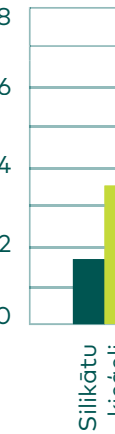

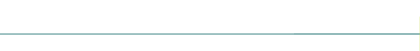
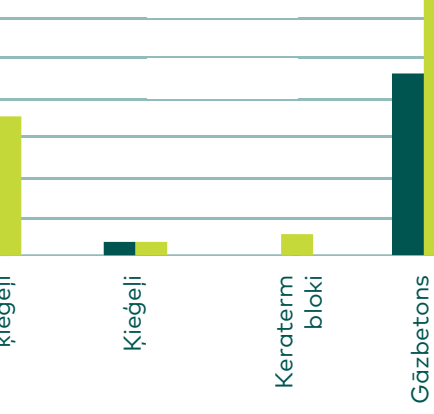

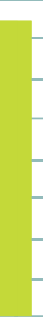

$n$
$C$
0
+0
0
$N$
10
0

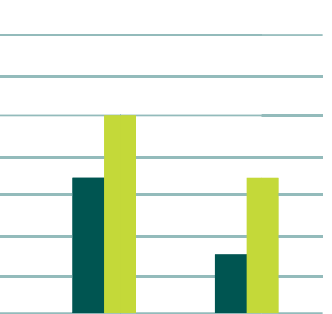

\begin{tabular}{l}
$n$ \\
\multicolumn{1}{c}{} \\
0 \\
+0 \\
0 \\
0
\end{tabular} $0-6^{\circ} \mathrm{C}$

$34-36^{\circ} \mathrm{C}$
2. att. Līdzsvara mitrums pētītajiem komerciālajiem sienu celtniecības materiāliem. 
sala izturība ir tieši saistīta ar kritisko poru izmēru 0,5-1,0 $\mu$ m diapazonā [2]. Ir pētīta poru struktūra Latvijas devona Liepas un Kupravas atradṇu un kvartāra Līvānu atradnes mālu keramikā. Keramikas materiāla porainības palielināšanai izmantotas neorganiskas un organiskas piedevas: dolomīta milti, sijātas zāǵu skaidas, kafijas sausna.

Analizēta poru struktūras veidošanās illìta mālu matricā ar un bez dabīga karbonātu piemaisījuma. No plastiskas masas ekstrudētai Liepas mālu keramikai raksturīgas izstieptas formas poras, kas orientētas ekstrūzijas virzienā. Šāda poru orientācija un forma saistīta ar mālu minerālu plākšn,veida uzbūvi (3. $a$ att.). Keramikas izstrādājumos, kas veidoti ar pussauso pan̄ēmienu, arī saglabājas šāda devona māliem raksturīga poru forma (3. $b$ att.).

Karbonātu klātbūtne devona perioda Kupravas mālos dod priekšstatu par illīta un kalcīta mijiedarbību apdedzināšanas procesā. Termiskās disociācijas rezultātā $1050{ }^{\circ} \mathrm{C}$ temperatūrā kalcīta graudu izmēri samazinās, un kontaktvirsmā starp illītu un kalcītu rodas atstarpe (4. $a$ att.). Sākotnējā kontaktzonā starp illītu un kalcītu (4. b att.) var konstatēt mijiedarbības kristāliskās fāzes - diopsīdu un anortītu. Pēc poru formas un to noapal,ojuma redzams, ka matricu veidojošais illītu saturošais materiāls ir ar zemāku saksepšanas temperatūru.

Karbonātus saturošos kvartāra mālos poras veidojas gan illīta sak̦epšanas, gan karbonātu termiskās sadalīšanās rezultātā. Papildus poru veidošanos var panākt, pievienojot dažādas poras veidojošas piedevas. Pievienojot vienlaicīgi atšḳirīgas dabas un izmēru poras veidojošas piedevas, apdedzinātā materiālā iegūstamas poras plašā diametru diapazonā. Siltumizolējošas keramikas ražošanai kvartāra mālu vidējā

a

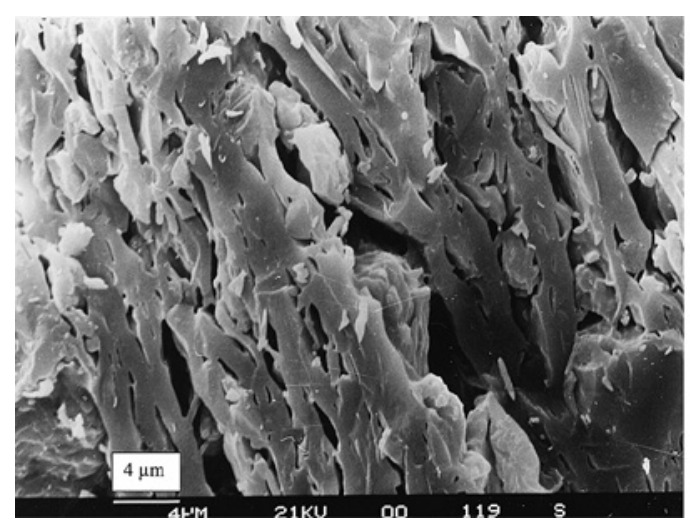

b

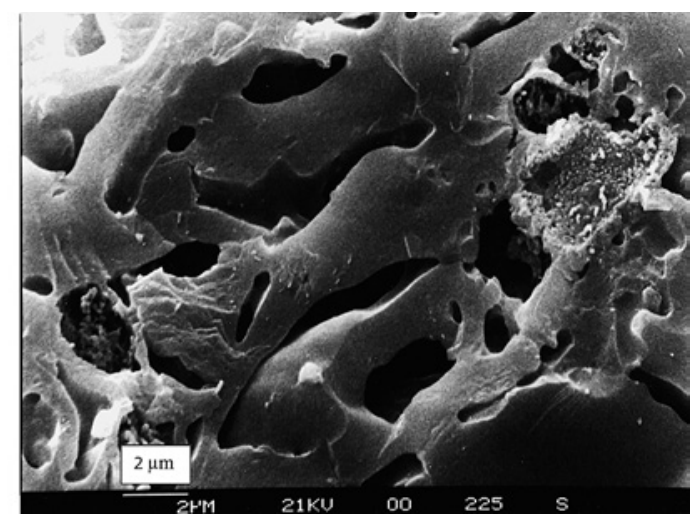

3. att. $1000{ }^{\circ} \mathrm{C}$ temperatūrā apdedzinātas Liepas mālu keramikas mikrostruktūra: a - ekstrudēta plastiska masa; b - pussausa presēta masa. 
apdedzināšanas temperatūra ir $1000^{\circ} \mathrm{C}$. Iegūstot Līvānu mālu keramiku no māliem bez piedevām, materiāla porainība ir 36,7 \% un struktūrā veidojas poras šaurā izmēru diapazonā, vidēji $0,44 \mu \mathrm{m}$ (5. $a$ att.). Materiāla drumstalas siltuma vadāmība ir $0,404 \mathrm{~W} \cdot \mathrm{m}^{-1} \cdot \mathrm{K}^{-1}$. Pievienojot māliem dolomīta miltus, zāgu skaidas un kafijas sausnu, iegūst keramikas materiālu ar porainību 57,5 \% un struktūrā veidojas poras plašā izmēru diapazonā. Materiāla drumstalas siltuma vadāmība ir $0,187 \mathrm{~W} \cdot \mathrm{m}^{-1} \cdot \mathrm{K}^{-1}$. Porozimetrijas rezultāti par koksnes skaidu ietekmi uz poru izmēriem liecina par to, ka starp mālvielu un organisko komponenti - koksnes skaidām - pastāv arī fizikāli k̦īmiska iedarbība. Šì fizikāli k̦īmiskā iedarbība izpaužas kā poru veidošanās nanoizmēru diapazonā 10-100 nm (5. $b$ att.). Maksimālo poras veidojošo piedevu daudzumu ierobežo keramikas izstrādājumu plastiskais veidošanas pan̄ēmiens. Atseviško poras veidojošo komponentu salīdzinoša analīze rāda, ka siltuma vadāmības samazināšanai efektīvas ir nanoizmēru poras.

N̦emot vērā pasaules vides aizsardzībai svarīgu uzstādījumu - siltuma procesos izdalītā $\mathrm{CO}_{2}$ daudzuma samazināšanu, veikti pētījumi par citām porainas keramikas iegūšanas iespējām, izslēdzot organiskas izcelsmes piedevu sadedzināšanu keramikas termiskās apstrādes tehnologijā.

Porainu siltumu izolējošu keramiku iespējams iegūt arī ar koncentrētas suspensijas liešanas paṇēmienu, kur poru veidošanās notiek ūden,raža izdalīšanās rezultātā, reaǵējot pulverveida alumīnijam ar ūdeni bāziskā vidē. Šì tehnoloǵija nedaudz atgādina gāzbetona ražošanas tehnoloǵiju. Gatavojot izstrādājumus ar suspensijas liešanas paṇēmienu, poru veidošanās šajā suspensijā ir atkarīga no reologiskajām īpašībām, piemēram, zeta potenciāla, viskozitātes un pH. Gāzes veidošanās

a

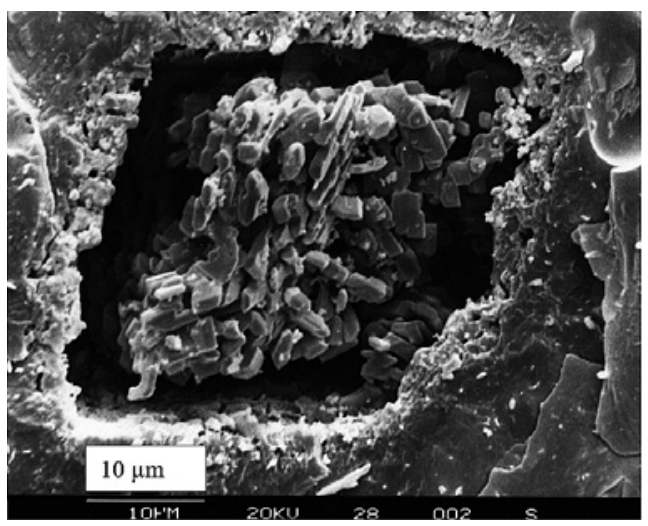

b

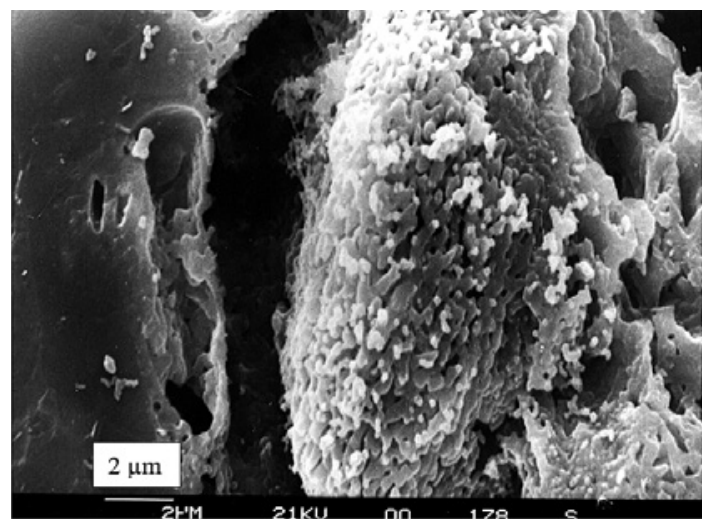

4. att. Illīta un kalcīta augsttemperatūras iedarbība Kupravas mālos:

a - dekarbonizēts kalcīta grauds; b - iedarbības robežslānis. 
reakcijas ātrums, alumīnija pulverim reaǵējot ar ūdeni, ir atkarīgs no noteiktu minerālu klātbūtnes, piemēram, kaolinīta, ilìta, smektītu un arī alumīnija oksīda. Ūden,raža izdalīšanās ātrums suspensijā nosaka arī materiāla porainību. Gala produkta poru struktūru ietekmē arī izejvielu graudu izmēri un apdedzināšanas temperatūra. Savukārt suspensijas viskozitāte ir tā, kas nosaka poru veidu - tās ir vai nu apaḷas, vai ovālas. Metastabila poru struktūra izveidojas stundas laikā suspensijai

a

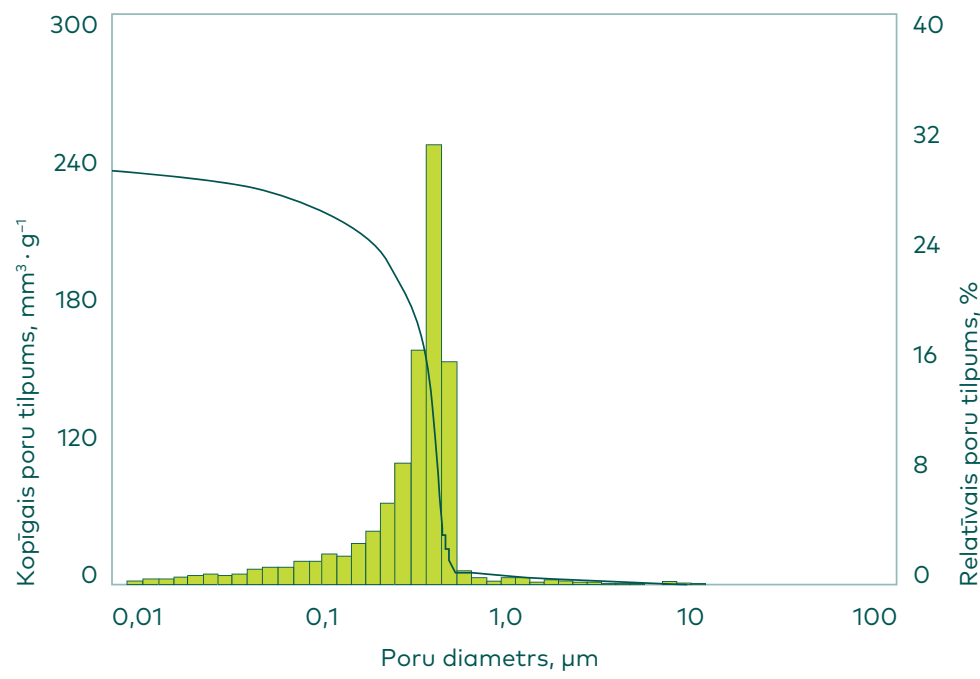

b

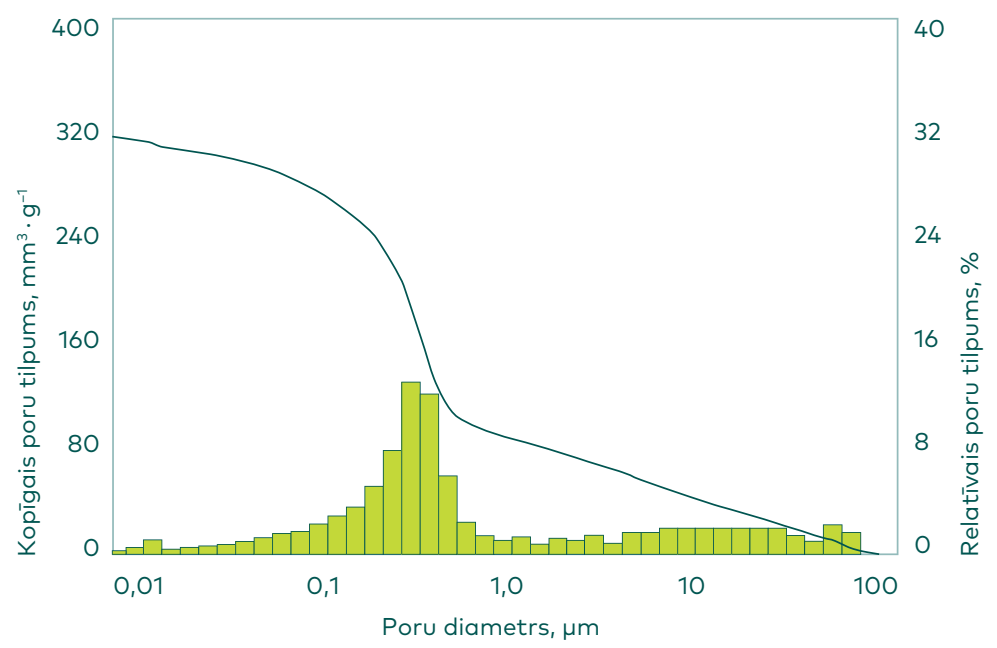

5. att. Poru izmēru un tilpuma sadalījums Līvānu mālu celtniecības keramikā pēc apdedzināšanas $1000^{\circ} \mathrm{C}$ :

a - māli bez piedevām; b - māli ar 20 \% zāǵu skaidu piedevu. 
sacietējot [3]. Pievienojot izejvielu maisījumam smalku alumīnija pulveri vai pastu ar vidējo daḷiṇu izmēru $15 \mu \mathrm{m}$, poru izmēru sadalījums apdedzinātos paraugos ir atšķirīgs dažādiem māliem. Bezkarbonātu devona mālu keramikai pēc optiskās mikroskopijas rezultātiem poras ir lielākas un relatīvais poru virsmas laukums $1000^{\circ} \mathrm{C}$ temperatūrā apdedzinātiem paraugiem ir 49,5 \%, bet kvartāra mālu keramikā, kas arī apdedzināta $1000{ }^{\circ} \mathrm{C}$ temperatūrā, poras ir mazākas un relatīvais poru virsmas laukums ir 29,7 \%. Arī poru izmēru sadalījums šajos keramikas materiālos ir atšķirīgs. Bezkarbonātu mālu keramikas materiāla poru sadalījuma diagrammā ir divi raksturīgi poru izmēru diapazoni 0,01-1,0 $\mu \mathrm{m}$ un 10-100 $\mu \mathrm{m}$. Turpretim karbonātu mālu keramikas poru sadalījuma diagramma uzrāda trīs raksturīgus poru izmēru diapazonus: 0,01-0,1 $\mu \mathrm{m}$ (I), ap 1,0 $\mu \mathrm{m}$ (II) un 10-100 $\mu \mathrm{m}$ (III), skat. 6. att.

Lielākā izmēra poru veidošanās saistīta ar ūdeņraža izdalīšanos ķīmiskās reakcijas rezultātā un suspensijas sacietēšanu. Vidējā izmēra poras veidojas mālu minerālu dehidroksilācijas rezultātā, bet mazāko poru veidošanās notiek karbonātu sadalīšanās rezultātā. Smalkākās poras nodrošina siltuma izolāciju un ūdens tvaika adsorbciju, bet lielās rada rezerves tilpumu ūdens sasalšanas gadījumā. Šādu materiālu tilpuma masa ir maza - bezkarbonātu mālu gadījumā $1,0-1,17 \mathrm{~g} \cdot \mathrm{cm}^{-3}$, bet karbonātus saturošu mālu keramikas gadījumā $0,97-1,0 \mathrm{~g} \cdot \mathrm{cm}^{-3}$. Pastāv lineāra sakarība starp silikātu keramikas tilpuma masu un siltuma vadāmības koeficientu $\lambda$. No šĩ viedokḷa aprēḳinātais siltuma vadāmības koeficients bezkarbonātu mālu keramikai ir $0,15 \mathrm{~W} \cdot \mathrm{m}^{-1} \cdot \mathrm{K}^{-1}$, bet karbonātu mālu keramikai tas ir $0,13 \mathrm{~W} \cdot \mathrm{m}^{-1} \cdot \mathrm{K}^{-1}$.

Izmantojot keramikas izstrādājumu veidošanu ar plastisko paṇēmienu, māliem pievienoti 1 masas\% vai 5 masas\% rupjgraudainu alumīnija pulveru ar vidējo daḷiņu izmēru $100 \mu \mathrm{m}$ vai $630 \mu \mathrm{m}$. Apdedzinot



6. att. Poru izmēru sadalījums $1000^{\circ} \mathrm{C}$ temperatūrā apdedzinātā kvartāra mālu keramikā. 
paraugus klasiskajās Latvijas mālu apdedzināšanas temperatūrās $950{ }^{\circ} \mathrm{C}$, $1000{ }^{\circ} \mathrm{C}$ un $1050{ }^{\circ} \mathrm{C}$, iegūti materiāli ar atšksirīgām īpašībām. Īpašības stipri ietekmē gan pievienotā rupjgraudainā alumīnija pulvera daḷinu izmērs, gan daudzums. Apdedzināšanas temperatūras ietekme arī ir atšksirīga. Devona mālu keramikas piedevas dažādi ietekmē ūdens uzsūkšanas spēju, salīdzinot ar dabīgiem māliem. 1 masas\% $100 \mu \mathrm{m}$ alumīnija pulvera piedeva $950{ }^{\circ} \mathrm{C}$ un $1000{ }^{\circ} \mathrm{C}$ temperatūrā apdedzinātu paraugu ūdens uzsūci samazina salīdzinājumā ar keramiku bez piedevas. Turpretim $1050{ }^{\circ} \mathrm{C}$ temperatūrā apdedzinātu paraugu ūdens uzsūce palielinās. 5 masas\% $100 \mu \mathrm{m}$ alumīnija pulvera piedeva veicina keramikas ūdens uzsūces palielināšanos visās izvēlētajās apdedzināšanas temperatūrās. Savukārt rupjākā $630 \mu \mathrm{m}$ alumīnija pulvera gan 1 masas\%, gan 5 masas\% piedeva visās temperatūrās apdedzinātu paraugu ūdens uzsūci samazina, salīdzinot ar apdedzinātu mālu paraugu ūdens uzsūci. Tādas pašas piedevas kvartāra māliem ūdens uzsūci ietekmē atšķirīgi. $100 \mu \mathrm{m}$ alumīnija pulvera piedevas 1 masas\% un 5 masas\% daudzumā palielina ūdens uzsūci paraugiem, kas apdedzināti visās izvēlētajās temperatūrās. Savukārt $630 \mu \mathrm{m}$ pulvera piedeva ḷoti maz izmaina apdedzināto paraugu ūdens uzsūci, salīdzinot ar atbilstošajās temperatūrās apdedzinātu kvartāra mālu ūdens uzsūci. Tāpēc uzlabotas siltuma vadāmības materiālu iegūšanai, izmantojot rupjgraudainu alumīnija pulveri, noderīgāki ir kvartāra perioda karbonātus saturoši māli ar nelielu (1-5 masas\%) alumīnija pulvera piedevu ar graudu vidējo izmēru $100 \mu \mathrm{m}$.

Celtniecības keramikas gadījumā svarīga loma ir materiālu spiedes izturībai. Ūdens uzsūces un atbilstoši porainības palielināšanās gadījumā materiālu mehāniskā izturība samazinās. Saglabājoties vispārīgajai sakarībai starp keramikas ūdens uzsūci (porainību) un mehānisko izturību, ir redzams, ka izmantotās piedevas un to daudzums tomēr neviennozīmīgi ietekmē šo zināmo sakarību. Devona mālu keramikas gadījumā $100 \mu \mathrm{m}$ alumīnija pulvera piedeva samazina paraugu spiedes izturību visās apdedzināšanas temperatūrās. Turpretim rupjgraudainā $630 \mu \mathrm{m}$ alumīnija pulvera piedeva ievērojami palielina keramikas paraugu spiedes izturību $1000{ }^{\circ} \mathrm{C}$ un $1050{ }^{\circ} \mathrm{C}$ temperatūrās apdedzinātiem paraugiem. 1 masas\% piedevas gadījumā sevišķ efektīvs spiedes izturības pieaugums ir $1050{ }^{\circ} \mathrm{C}$ temperatūrā apdedzinātiem paraugiem. $950{ }^{\circ} \mathrm{C}$ temperatūrā apdedzinātu paraugu spiedes izturība samazinās, salīdzinot ar šajā temperatūrā apdedzinātas keramikas bez piedevām spiedes izturību. Rezultāti par devona un kvartāra mālu keramikas ūdens uzsūci un spiedes izturību $1050{ }^{\circ} \mathrm{C}$ temperatūrā apdedzinātiem materiāliem apkopoti I. tabulā.

Optiskās mikroskopijas fotoattēlā (7. att.) redzams, ka rupjgraudainā alumīnija pulvera graudi $(630 \mu \mathrm{m})$ keramikas sastāvā apdedzināšanas rezultātā darbojas kā reducētājs, reducējot mālu sastāvā esošo $\mathrm{Fe}_{2} \mathrm{O}_{3}$ par $\mathrm{FeO}$ un veicinot stiklveida fāzes rašanos zemākā temperatūrā. Veidojas 
$1050^{\circ} \mathrm{C}$ temperatūrā apdedzinātas keramikas ūdens uzsūce un spiedesizturība

\begin{tabular}{cccccc}
\hline \multicolumn{2}{c}{ Devona mālu keramika } & \multicolumn{2}{c}{ Kvartāra mālu keramika } \\
\hline $\begin{array}{c}\text { Sastāva } \\
\text { apzīmējums }\end{array}$ & $\begin{array}{c}\text { Ūdens } \\
\text { uzsūce, } \\
\%\end{array}$ & $\begin{array}{c}\text { Spiedes } \\
\text { izturība, } \\
\text { MPa }\end{array}$ & $\begin{array}{c}\text { Sastāva } \\
\text { apzīmējums }\end{array}$ & $\begin{array}{c}\text { Ūdens } \\
\text { uzsūce, } \\
\%\end{array}$ & $\begin{array}{c}\text { Spiedes } \\
\text { izturība, } \\
\text { MPa }\end{array}$ \\
\hline māli & 5,8 & 56,1 & māli & 15,1 & 61,0 \\
D1-1 & 6,6 & 47,9 & K1-1 & 18,5 & 36,3 \\
D1-5 & 11,0 & 37,4 & K1-5 & 18,9 & 35,6 \\
D6-1 & 4,8 & 68,2 & K6-1 & 15,1 & 59,0 \\
D6-5 & 4,3 & 68,1 & K6-5 & 14,2 & 35,8 \\
\hline
\end{tabular}

noslēgtas poras ar tumšām poru sieniṇām alumīnija graudu kontakta zonā ar mālu matricu, kas tad arī nosaka materiāla spiedes izturības palielināšanos. Analizējot iegūtos rezultātus, jāsecina, ka materiāla iegūšana ar vēlamajām īpašībām ir atkarīga ne vien no mālu izejvielas rakstura un apdedzināšanas temperatūras, bet arī no pievienojamā alumīnija pulvera graudu izmēra un daudzuma. Izmantojot alumīnija pulveri ar daḷiņu izmēru 10-20 $\mu \mathrm{m}$, keramikas izstrādājumi iegūstami no suspensijas (šlikera) ar mitruma saturu 32 \%. No devona māliem ar liešanas pañēmienu iegūtas apdedzinātas keramikas porainība ir ievērojami augstāka un siltuma vadītspēja ir ievērojami zemāka. Izmantojot 1-5 masas \% rupjgraudaina alumīnija pulveri, iegūtā materiāla ūdens uzsūce (un arī porainība) mainās nedaudz, tāpēc ievērojama siltuma vadāmības samazināšanās nav sagaidāma. Tieši otrādi, ir novērojama pretēja parādība - $1050{ }^{\circ} \mathrm{C}$ temperatūrā apdedzinātu paraugu ūdens uzsūce ir mazāka nekā šajā pašā temperatūrā apdedzinātu mālu keramikai bez piedevām. Tāpēc rupjgraudainā $(630 \mu \mathrm{m})$ alumīnija pulvera

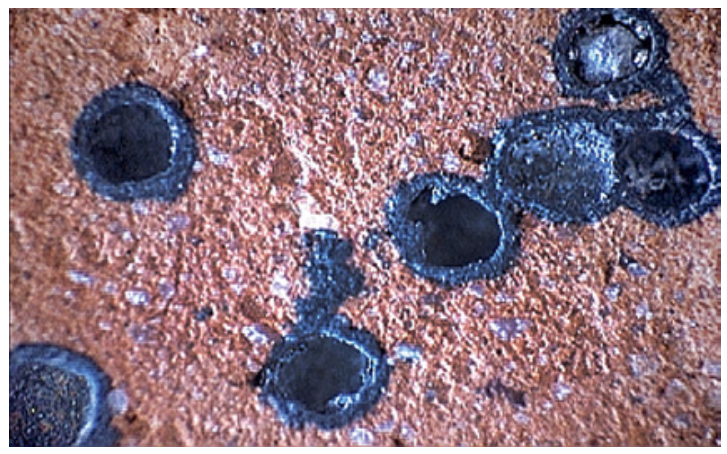

7. att. Slēgtu poru veidošanās mālu matricā (devona māli ar 5 masas\% $630 \mu \mathrm{m}$ alumīnija pulvera piedevu). Apdedzināšanas temperatūra $-1050^{\circ} \mathrm{C}$. 
piedeva ir noderīga klinkera tipa keramikas iegūšanai ar ūdens uzsūci $\leq 6 \%$ un paaugstinātu mehānisko izturību. Metāliska alumīnija pulveris kā izejviela ar graudu izmēriem plašā diapazonā (no $15 \mu \mathrm{m}$ suspensijā līdz 100-630 $\mu \mathrm{m}$ plastiskā mālu masā) l̦auj iegūt porainu keramiku ar samazinātu siltuma vadāmību. Ar šo paṇēmienu iespējams samazināt oglekḷa dioksīda emisiju, kas vienmēr pavada ilgmūžīgas celtniecības keramikas ražošanu. Keramikas materiāli, kas iegūti ar koncentrētas suspensijas liešanas metodi, ir vērtīgs celtniecības materiāls telpām ar augstu mitruma saturu, jo šim materiālam ir zems līdzsvara mitruma saturs $(W \leq 1,4 \%$ pēc 1 mēneša izturēšanas telpā ar relatīvo mitrumu līdz 95 \%).

\section{Keramzīts (šūnaina keramika)}

Keramzīts ir labi pazīstams, viegls, keramisks granulveida materiāls, kuru mūsdienās izmanto galvenokārt kā rupjo pildvielu vieglu betona izstrādājumu ražošanai. Pārsvarā pastāv viedoklis, ka keramzīta ražošanai noderīgi ir viegli kūstoši hidrovizlas saturoši māli, kuros ir pietiekoši augsts dzelzs oksīdu saturs. Strauji cel̦ot temperatūru $1000-1150{ }^{\circ} \mathrm{C}$ intervālā, atkarībā no mālu ḳīmiskā sastāva, intensīvi izdalās gāzes. Tā kā apdedzināmais materiāls ir piroplastiskā stāvoklī, ko rada augstas viskozitātes šksidrās fāzes klātbūtne, tad gāzes saglabājas materiāla iekšienē un to uzpūš. Gāzes rodas mālu minerālu un to piemaisījumos esošo karbonātu sadalī̌sanās rezultātā un oglekḷa savienojumu klātbūtnē $\mathrm{Fe}_{2} \mathrm{O}_{3}$, reducējoties par $\mathrm{FeO}$ un izdalot $\mathrm{CO}$ un skābekli. Pētīti dažādi Latvijas māli, gan kvartāra ǵeologiskā perioda (Līvāni, Apriḳi, Nīcgale), gan devona perioda Kupravas atradnes māli [4]. Visi izmantotie māli satur karbonātu piemaisījumus dažādos daudzumos. Mālu uzpūšanās uzlabošanai izmantotas dažādas piedevas: zāğu skaidas 3-5 masas\%, ellı 1-3 masas\%, koksnes pulēšanas putekḷi 1-5 masas\%, kafijas sausna 3 masas\%. Keramikas masas sagatavotas plastiskā veidā ar mitruma saturu $20 \%$. Paraugi pēc izžāvēšanas apdedzināti klasiskajā divpakāpju režīmā. Klasiskā tehnoloǵija (divstadiju process) paredz lēnu pakāpenisku temperatūras celšanu līdz $850^{\circ} \mathrm{C}$. Temperatūras celšanas ātrumu ierobežo adsorbētā un k̦īmiski saistītā ūdens izdalīšanās no mālu minerāliem. Tālāk notiek strauja temperatūras celšana līdz $1100-1200{ }^{\circ} \mathrm{C}$ un izturēšana maksimālajā temperatūrā. Otrās apdedzināšanas stadijas laikā veidojas granulu iekšējā šūnainā struktūra, jo tajā veidojas reducējoša apdedzināšanas vide, un granulas apvalks sablīvējas saḳepšanas rezultātā. Svarīgs keramzīta izejvielu raksturojošs lielums ir uzpūšanāsdeformācijas temperatūra un atbilstošais temperatūras intervāls. 8. att. 
parādīta Apriķu mālu granulu uzpūšanās, tās apdedzinot dažādos divpakāpju termiskās apstrādes režīmos.

Analizējot darba gaitā iegūtos rezultātus, ir redzams, ka keramzīta iegūšana ir atkarīga no daudziem faktoriem. Vispirms jau tas ir mālu k̦īmiskais un mineraloǵiskais sastāvs. Pētītie māli ir hidrovizlu māli, bet dažos rentgena fāžu analīze uzrāda arī nelielu kaolinīta daudzumu. Ķīmiskā analīze uzrāda dažādu $\mathrm{Fe}_{2} \mathrm{O}_{3}$ saturu. Lielākais $\mathrm{Fe}_{2} \mathrm{O}_{3}$ saturs ir Prometeja mālos, bet mazākais Nīcgales mālos. L̦oti atšķirīgs ir arī CaO saturs - no 11,30 \% Apriķu mālos līdz 3,29 \% Kupravas mālos. Agrāk literatūrā norādītie $\mathrm{Fe}_{2} \mathrm{O}_{3}$ un $\mathrm{CaO}$ piel̦aujamie $(\mathrm{CaO} \leq 5-6 \%$ ) vai nepieciešamie $\left(\mathrm{Fe}_{2} \mathrm{O}_{3} 6-9 \%\right)$ daudzumi mūsu iegūto rezultātu izvērtējumā nav noteicošie.

a

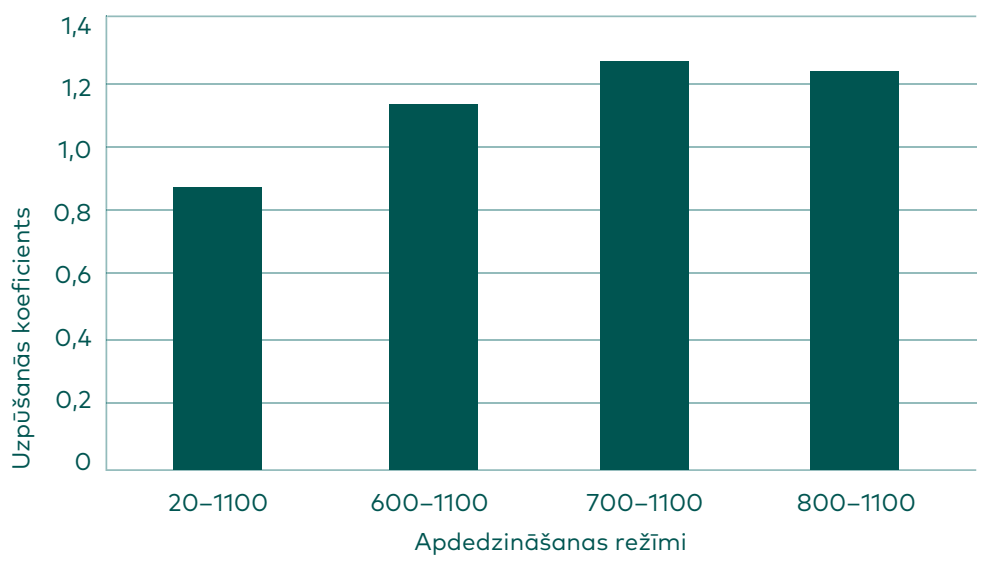

b

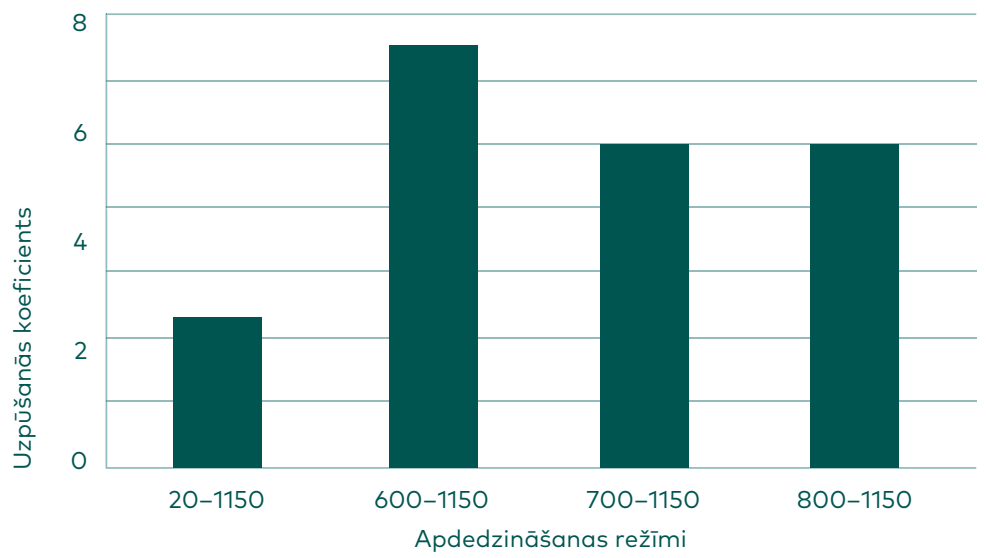

8. att. Apriķu mālu uzpūšanās dažādos apdedzināšanas režīmos ar $2 \%$ ellıas piedevu: a - maksimālā temperatūra $1100^{\circ} \mathrm{C} ; \mathrm{b}$ - maksimālā temperatūra $1150{ }^{\circ} \mathrm{C}$. 
Apriḳu mālos $\mathrm{CaO} / \mathrm{Fe}_{2} \mathrm{O}_{3}$ attiecība ir 1,58, Prometeja mālos šĩ attiecība ir 0,55 , bet abi māli ar vienām un tām pašām piedevām un vienādos tehnologiskos apstākḷos uzpūšas vislabāk. Svarīga nozīme ir arī piedevām, kas nodrošina nepieciešamo oglekḷa daudzumu, kurš veicina $\mathrm{Fe}_{2} \mathrm{O}_{3}$ reducēšanu par FeO, kā arī oglekli saturošu piedevu daudzumam. Vislabāko rezultātu mūsu gadījumā dod piedevas, kuras strauji sadeg attiecīgajā izvēlētajā beigu temperatūrā. No darbā izmantotajām piedevām tā ir ellıa. Ja mālos $\mathrm{Fe}_{2} \mathrm{O}_{3}$ nav pietiekošā daudzumā, tad nepieciešams izmantot $\mathrm{Fe}_{2} \mathrm{O}_{3}$ saturošas piedevas. Tehnologiskajā ziṇā, kā redzams no pētījumiem, svarīgas ir pirmās stadijas temperatūra un ātrās apdedzināšanas maksimālā temperatūra [5].

Uzpūšanās koeficienta palielināšanai divstadiju paṇēmiena gadījumā pirmās pakāpes temperatūra izvēlēta zemāka par dehidroksilācijas temperatūru, kad mālu minerāli jau sāk sadalīties. Dehidroksilācijas process pēc tam varētu beigties otrajā stadijā, un var sagaidīt, ka ūdens tvaika izdalīšanās radīs papildus poras kopā ar tradicionālo šūnu keramikas veidošanās procesu, kad, dal̦ēji strauji sadegot organiskajai piedevai, reducējas Fe(III) oksīds un skābeklis kopā ar oglekḷa monoksīdu uzpūš drumstalu. Kā rāda iegūtie rezultāti, tad ne vienmēr notiek sagaidāmais process. Devona mālos (Kupravas, Tūjas un Planču atradnes) uzpūšanās šajā apdedzināšanas režīmā vispār nenotiek, jo $\mathrm{Fe}_{2} \mathrm{O}_{3}$ saturs ir tuvu literatūrā uzrādītajai zemākajai kritiskajai robežai ( $\geq 6 \%$ ) un putekḷu un smilšu frakciju kopīgais saturs ir lielāks par 20 \%. Kvartāra māli (Nīcgales, Apriķu un Prometeja atradnes) uzpūšas l,oti labi, bet īsā uzpūšanās-deformācijas intervāla dēl to praktiska izmantošana ražošanā bez liesinošām piedevām ir stipri apgrūtināta.

Pētītie Latvijas kvartāra un devona ǵeoloǵisko periodu māli ir noderīgi šūnu keramikas - keramzīta - ražošanai. Atkarībā no pētīto mālu ķīmiskā sastāva, tehnoloǵiskās iespējas iegūt keramzītu ir atšķirīgas. Ķīmiskā sastāva ziṇā svarīgākais ir dzelzs oksīda un kalcija oksīda saturs. $\mathrm{Fe}_{2} \mathrm{O}_{3}$ rada iespēju notikt reducēšanās procesam, bet papildus oglekli saturošu savienojumu klātbūtne pastiprina šo procesu. Galvenais faktors, kas nosaka keramzìta iegūšanas tehnologiskos parametrus, ir augsttemperatūras fāzes, kuras veidojas mālos ātrās apdedzināšanas rezultātā noteiktā temperatūrā. Savukārt svarīga nozīme ir šo augsttemperatūras fāžu viskozitātei, jo tā nodrošina gan poru veidošanos $\mathrm{Fe}_{2} \mathrm{O}_{3}$ reducēšanas, $\mathrm{O}_{2}$ izdalīšanās un $\mathrm{CO}$ veidošanās rezultātā, gan granulu apvalka saglabāšanos. Tāpēc noderīgākie keramzīta ražošanai ir māli, kuros augsttemperatūras reakciju rezultātā veidojas anortīts. Veikto pētījumu rezultātā konstatēts, ka no šiem keramzīta ražošanai vispiemērotākie ir kvartāra perioda Apriḳu māli ar $2 \%$ elllas piedevu, kas dod vislielāko uzpūšanās koeficientu, ja granulas tiek lēni uzkarsētas līdz $600{ }^{\circ} \mathrm{C}$ temperatūrai un pēc tam tiek pārvietotas $1150{ }^{\circ} \mathrm{C}$ temperatūrā. 
Ātrās apdedzināšanas tehnologijas ir viens no keramikas materiālu ražošanas attīstības galvenajiem virzieniem. Noteicošie faktori no māliem ražotas keramikas termiskās apstrādes ātrumam ir apdedzināšanas laikā notiekošie k̦īmiskie un fizikālie procesi. Ātrās apdedzināšanas tehnologijai līdz šim vismazāk vērības ir veltīts keramzīta (šūnainas keramikas) ražošanā. Šāds modernas tehnoloǵijas trūkums ir saistīts ar apdedzināšanas tehnologiiskajām iekārtām.

No dažādiem (gan pēc ǵeologiiskās izcelsmes, gan pēc mineraloǵiskā un ḳīmiskā sastāva) Latvijas māliem ar $2 \%$ zāǵu skaidu piedevu iegūtas šūnainas keramikas granulas ar atšķirīgu tilpuma masu un tilpuma palielināšanās koeficientu. Pamatprocess šāda keramikas materiāla iegūšanai ir kopējs - ātrā apdedzināšanas procesā noteiktā temperatūrā apdedzināmais materiāls ir piroplastiskā stāvoklī. Granulā pastāv temperatūras gradients, un uz granulas virsmas veidojas relatīvi blīvs, loti sīkporains apvalks, kas aiztur granulas iekšienē radušās dažādās gāzveida vielas, kuras, pateicoties paaugstinātam spiedienam granulas iekšienē, uzpūš granulu. Vieglu granulu iegūšanai ir trīs priekšnoteikumi: gāzveida vielas izdalīšanās temperatūra, šksidrā fāze ar atbilstoši nelielu viskozitāti un pietiekoši garu piroplastiskā stāvokḷa temperatūras intervālu un kristāliskās fāzes, kuras izveidojas keramikas materiālā apdedzināšanas temperatūrā. Liepas mālu granulu apdedzināšanas procesā gāzveida fāze ir ūdens tvaiki, kuri rodas mālu minerālu sadalīšanās rezultātā $500-600{ }^{\circ} \mathrm{C}$ temperatūru intervālā. Uzpūšanos nodrošina daḷeja izdegošo piedevu sadegšana, un radies $\mathrm{CO}$ reducē $\mathrm{Fe}_{2} \mathrm{O}_{3}$, izdalot skābekli. Liepas mālos $\mathrm{Fe}_{2} \mathrm{O}_{3}$ saturs ir 7,15 masas\%. Savukārt kristāliskās fāzes $1150{ }^{\circ} \mathrm{C}$ temperatūrā apdedzinātajā Liepas mālu materiālā ir tikai kvarcs un mullīts, kas abi ir grūti kūstoši savienojumi, un granulu tilpuma palielināšanās koeficients ir neliels. Līdzīgs process notiek arī ar juras perioda Strēlu atradnes mālos, kur apdedzinātais produkts arī satur tikai kvarca un mullīta kristāliskās fāzes. Keramzīta iegūšanai ar vienstadijas paṇēmienu tika izmantots devona perioda Tūjas mālu

II. tabula

Devona mālu keramzīta tilpuma masa pēc divu veidu termiskās apstrādes

\begin{tabular}{ccc}
\hline & \multicolumn{2}{c}{ Tilpuma masa, $\mathbf{g} \cdot \mathrm{cm}^{-3}$} \\
\hline Sastāvs & $\begin{array}{c}\text { Divu stadiju process } \\
20^{\circ} \mathrm{C} \rightarrow 500^{\circ} \mathrm{C} \rightarrow 1150^{\circ} \mathrm{C}\end{array}$ & $\begin{array}{c}\text { Vienas stadijas } \\
\text { process } \\
20^{\circ} \mathrm{C} \rightarrow 1200^{\circ} \mathrm{C}\end{array}$ \\
\hline Liepas māli $+25 \%$ smiltis & 1,77 & 1,11 \\
Planču māli $+25 \%$ smiltis & 0,95 & 0,72 \\
Tūjas māli (smilšaini) & 1,48 & 1,03 \\
\hline
\end{tabular}




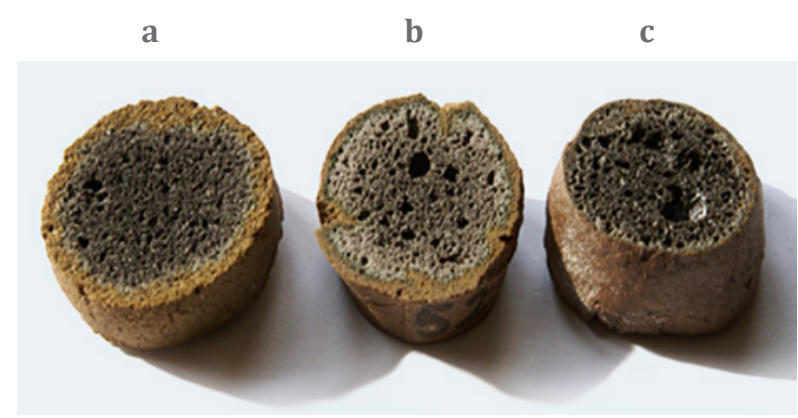

9. att. Ar vienstadijas paṇēmienu iegūto Liepas mālu ar 25 \% smilšu piedevu (a), Tūjas smilšaino mālu (b) un Planču mālu ar 25 \% smilšu piedevu (c) keramzīta granulas.

smilšains paraugs, bet Liepas un Planču māliem tika palielināts smilšu frakcijas saturs, pievienojot maltas smiltis, attiecīgi $50 \%$ un $25 \%$. Šo sastāvu granulas apdedzinātas gan pēc divstadiju, gan pēc vienstadijas paṇēmiena. Iegūto rezultātu salīdzinājums parādīts II. tabulā. Visos apskatītajos gadījumos vienas stadijas procesā iegūtās granulas ir ar mazāku tilpuma masu [6].

Redzams, ka visos trijos paraugos (9. att.) poru struktūra ir atšksirīga. Liepas mālu ar 25 \% smilšu piedevu granulās (a), kam ir vislielākā tilpuma masa no pētītajiem paraugiem, poras ir neliela izmēra, bet granulas virskārta ir visbiezākā. Tūjas smilšaino mālu granulās (b) poras ir ievērojami lielākas, un to krāsa ir gaišāka nekā pārējos paraugos, kas var liecināt par nepietiekošu $\mathrm{Fe}_{2} \mathrm{O}_{3}$ un/vai organisko piedevu daudzumu mālos. Savukārt Planču mālu ar 25 \% smilšu piedevu granulās (c), kam ir vismazākā tilpuma masa $\left(0,72 \mathrm{~g} \cdot \mathrm{cm}^{-3}\right)$, poras ir ar dažādu diametru. Granulas centrālā, augsti porainā dạ̣a ir tumšā krāsā, un blīvā virskārta ir visplānākā. $\mathrm{Fe}_{2} \mathrm{O}_{3}$ saturs šajos mālos ir ievērojami lielāks nekā Tūjas mālos. Ar dzīvsudraba porozimetrijas metodi noteiktā porainība un īpatnējās virsma dota III. tabulā.

Ķìmiskajam un granulometriskajam sastāvam un temperatūras celšanas ātrumam ir būtiska nozīme poraina keramikas materiāla keramzīta - apdedzināšanas procesā. Ātrais vienstadijas apdedzināšanas režīms dod iespēju iegūt porainu keramikas struktūru no mālu izejvielām ar ierobežotu mālvielu saturu, tādā veidā paplašinot līdz šim Latvijā zināmo izejvielu bāzi keramzīta ražošanai. Vienstadijas ātrais apdedzināšanas process, pēc tā modelēšanas laboratorijas apstākḷıs, dod iespēju iegūt keramzīta granulas ar biezāku ārējo apvalku un paaugstinātu mehānisko izturību. Vienstadijas apdedzināšanas procesam nepieciešams paaugstināts $\mathrm{Fe}_{2} \mathrm{O}_{3}$ saturs izejvielās ( $\geq 6 \%$ ) 
Keramzīta raksturojums pēc dzīvsudraba porozimetrijas rezultātiem

\begin{tabular}{ccc}
\hline $\begin{array}{c}\text { Māli un keramzīta iegūšanas } \\
\text { paṇēmiens }\end{array}$ & Porainība, \% & İpatnējā virsma, $\mathbf{m}^{2} \cdot \mathbf{g}^{-1}$ \\
\hline Prometejs, divu stadiju & 52,73 & 37,46 \\
Kuprava, divu stadiju & 15,12 & 7,47 \\
Tūja, divu stadiju & 17,85 & 8,62 \\
Planči, divu stadiju & 28,44 & 5,79 \\
Planči, vienas stadijas & 29,64 & 3,26 \\
Tūja, vienas stadijas & 35,79 & 4,85 \\
\hline
\end{tabular}

un sīkdispersa $\mathrm{SiO}_{2}$ saturs $15-50$ \%. Pēc porozimetrijas datiem vienas pakāpes apdedzināšanas procesā iegūto granulu ārējais apvalks ar daḷēji caurlaidīgu poru struktūru ir piemērots sorbcijas procesiem un mikrobiologijas tehnologijām.

Šūnu keramikas veidošanās process Latvijas devona, juras un kvartāra mālos notiek atšķirīgi [7]. Atkarībā no mālu ķīmiskā un mineraloğiskā sastāva un nepieciešamajām iegūstamā materiāla īpašībām, jāizvēlas noteikts termiskās apstrādes režìms, piedevu daudzums un veids. No devona māliem, no kuriem šajā darbā izmantoti tikai Liepas atradnes māli, ar nelielu izdegošo piedevu daudzumu vienas pakāpes režīmā iespējams iegūt vieglas porainas granulas. Kā rāda termiskās analīzes līkṇu izmainas, devona mālos kausējuma veidošanās process sākas virs $900{ }^{\circ} \mathrm{C}$ un norit divos posmos, starp kuriem notiek jaunu kristālisko fāžu veidošanās. No Latvijas karbonātus saturošiem kvartāra māliem, ja tajos dzelzs(III) oksīda saturs ir 6-7 masas\%, iespējams iegūt vieglas šūnainas struktūras granulas arī bez izdegošām piedevām vai arī tad, ja izdegošo piedevu daudzums ir neliels. Termiskās apstrādes laikā

a

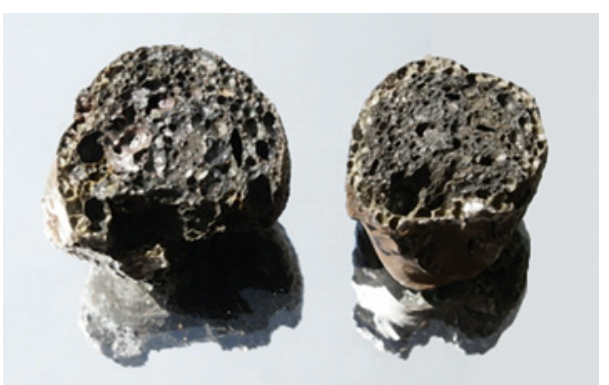

10. att. Ar divstadiju pan̄ēmienu iegūtas Apriķu (a) un Nīcgales (b) keramzīta granulas. 
a

Devona māli (Baikas)
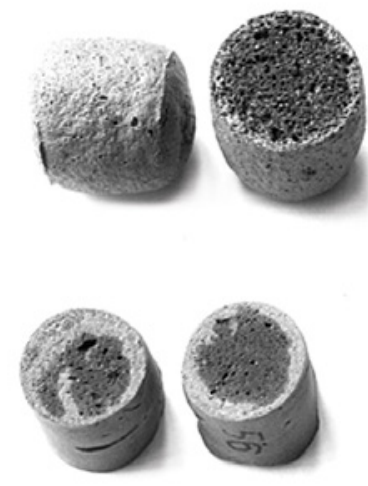

c

Devona māli (Planči 1) ar $15 \%$ maltu smilšu b

Devona māli (Tūja)
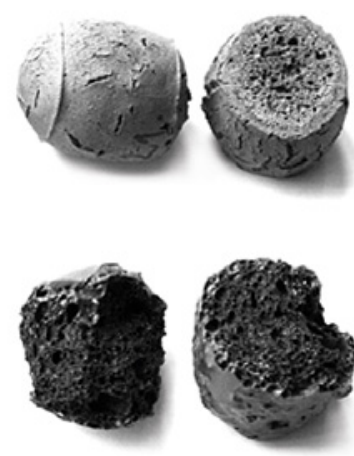

d

Kvartāra māli (Nīcgale)
Celtniecības

keramika,

keramzīts un

keramiskie sorbenti

granulu piroplastisko stāvokli nodrošina neliela šķidrās fãzes daudzuma klātbūtne, ar ko saistīta dzelzs oksīda klātbūtne mālos, vai arī kālija laukšpata, vai kalcija laukšpata (anortīta) klātbūtne, kuru kušanas temperatūra ir attiecīgi $1160{ }^{\circ} \mathrm{C}$ un $1500{ }^{\circ} \mathrm{C}$ (10. att.). Materiālu atdzesējot pēc termiskās apstrādes, kālija un kalcija laukšpati kristalizējas, veidojot mikroklīna un anortīta kristāliskās fāzes.

Salīdzinot ar keramzìta granulām, kas iegūtas divu stadiju apdedzināšanas procesā, vienas stadijas procesā iegūtajām granulām veidojas samērā blīvs 2-3 mm biezs apvalks (11. $a, b, c$ att.), kas aptver izteikti porainu iekšējo daḷu. Šādā veidā iegūtu keramzīta granulu tilpuma masa

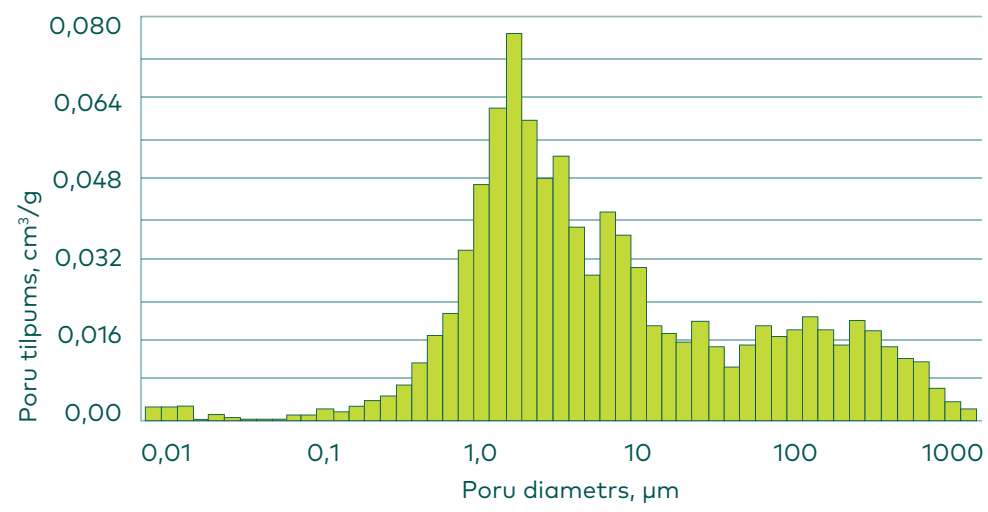

12. att. Poru izmēru sadalījuma histogramma keramzīta granulu virskārtā. 


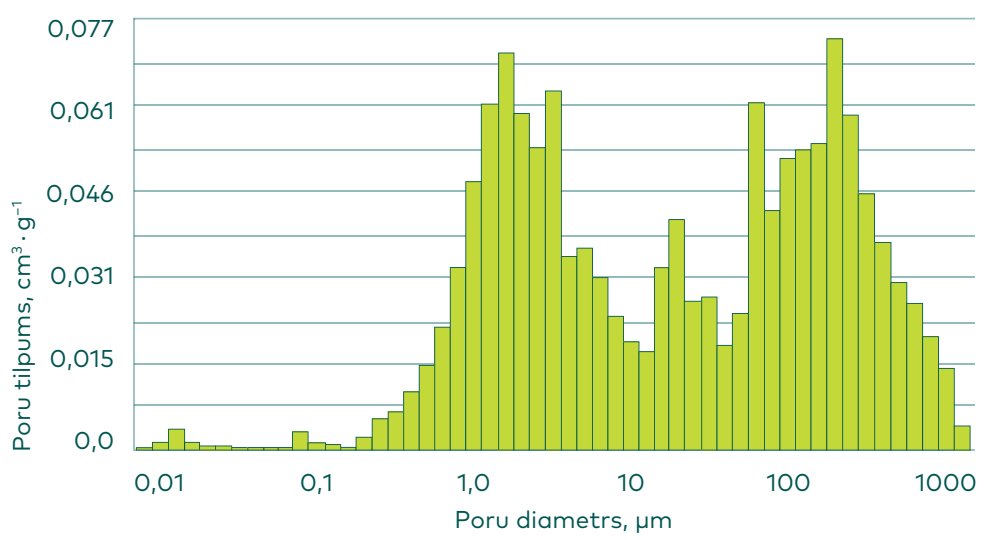

13. att. Poru izmēru sadalījuma histogramma keramzīta granulu vidusdaḷā.

ir 0,52-0,84 $\mathrm{g} \cdot \mathrm{cm}^{-3}$. Iegūstot keramzìtu no kvartāra māliem ar divu stadiju paṇēmienu, keramzīta tilpuma masa ir ievērojami mazāka, bet granulām ir l̦oti plāna, stiklaina virskārta (11. $d$ att.), un tā mehāniskā izturība ir neliela.

Granulas virskārtā (12. att.) pārsvarā ir poras 0,1-50 $\mu \mathrm{m}$ diapazonā, bet lielāko poru (100-1000 $\mu \mathrm{m})$ tilpums ir neliels un nepārsniedz $0,016 \mathrm{~cm}^{3} \cdot \mathrm{g}^{-1}$. Šo poru kopīgais virsmas laukums ir $6,44 \mathrm{~m}^{2} \cdot \mathrm{g}^{-1}$, un no porozimetrijas rezultātiem aprēķinātā tilpuma masa ir $0,37 \mathrm{~g} \cdot \mathrm{cm}^{-3}$. Savukārt granulas vidusdaḷā (13. att.) poru izmēru diapazons ir līdzīgs kā virskārtā, bet ievērojami palielinās lielo poru (80-1000 $\mu \mathrm{m})$ tilpums. Keramzìta vidusdal̦as poru kopīgais virsmas laukums ir $4,34 \mathrm{~m}^{2} \cdot \mathrm{g}^{-1}$, un no porozimetrijas rezultātiem aprēḳinātā tilpuma masa ir $0,23 \mathrm{~g} \cdot \mathrm{cm}^{-3}$. Ātrai termiskai apstrādei izejvielu sastāvā ir jābūt samazinātam mālvielu saturam (15-30\%), paaugstinātam putekḷu un sīkdispersu smilšu saturam ( $\geq 60-80 \%$ ), tajā skaitā laukšpatu grupas minerāliem, kuru saturs $\geq 5 \%$ [8]. Ja devona māli ir mazkarbonātu ar nelielu kalcīta

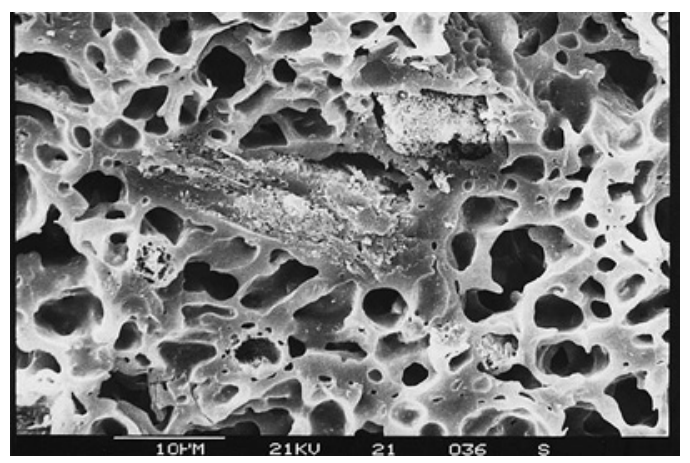

14. att. Kupravas mālu keramzìta vidus dalıs poras ar kalcīta sadalīšanās produktu ieslēgumiem. 
vai dolomīta saturu, piemēram, Tūjas un Kupravas māli, tad ātras terCeltniecības miskās apstrādes (10 min) rezultātā CaO nepaspēj pilnībā piedalīties keramzīts un keramiskie anortīta vai kausējuma veidošanā un var saglabāties porās nesaistītā sorbenti veidā (14. att.).

Tika pārbaudīti māli no vairākām Latvijas mālu atradnēm ar mērḳi noteikt to noderīgumu keramzīta ražošanai gan ar vienas stadijas, gan
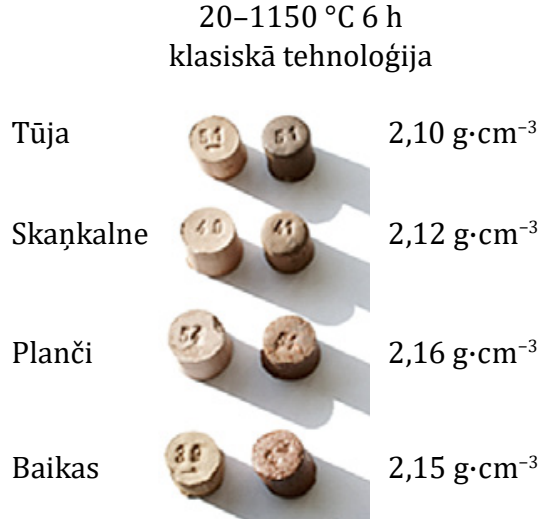

$20-1100{ }^{\circ} \mathrm{C} 10 \mathrm{~min}$

"termiskais trieciens"

15. att. Jauna termiskās apstrādes tehnologija šūnu keramikas (keramzīta) ražošanai.

$\begin{array}{ccc}20-700{ }^{\circ} \mathrm{C} & 20-550{ }^{\circ} \mathrm{C} & 20-550{ }^{\circ} \mathrm{C} \\ 30 \mathrm{~min} & 30 \mathrm{~min} & 30 \mathrm{~min}\end{array}$

$20-1100{ }^{\circ} \mathrm{C} \quad 700-1100{ }^{\circ} \mathrm{C} \quad 550-1100{ }^{\circ} \mathrm{C} \quad 550-1150{ }^{\circ} \mathrm{C}$

$90 \mathrm{~min} \quad 15 \mathrm{~min} \quad 15 \mathrm{~min}$ min

Kuprava

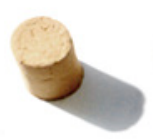

2,10

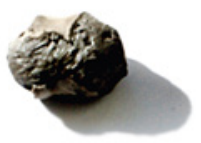

0,84

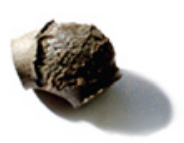

2,35

Ceplī̌si

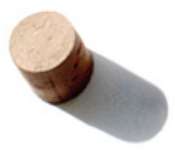

0,91

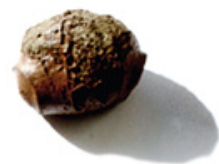

0,60

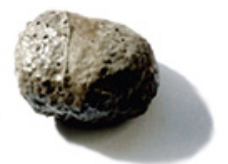

0,30

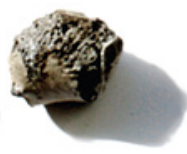

0,89

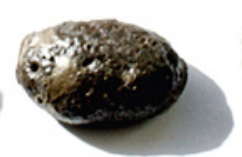

0,35

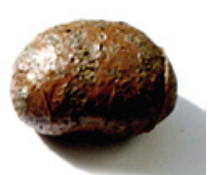

0,46

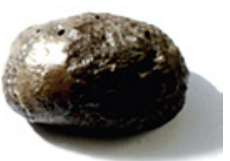

0,23

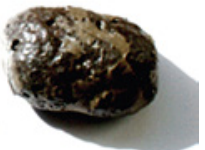

0,32
Augstas stiprības vieglās būvkonstrukcijās

Augstas stiprības vieglās būvkonstrukcijās

Mikrobiologijas tehnologijām

Siltumizolācijai

16. att. Divstadiju termiskās apstrādes process, koksnes skaidu piedeva -2 masas\%. 
ar divu stadiju paṇēmieniem. Dal̦a iegūto rezultātu apkopota 15. att. un 16. att., kur blakus granulām parādīta arī šo granulu tilpuma masa.

\section{Keramiskie sorbenti}

Pieaugot apkārtējās vides piesārṇojumam ar dažādām vielām smago metālu savienojumiem, šksīinātājiem, u. c., arvien pieaug pieprasījums pēc sorbentiem, filtriem, sorbējošām un filtrējošām membrānām u. tml. L Loti piemērots materiāls vides attīrīšanas tehnologijām ir māls un keramikas materiāli uz māla bāzes. Keramisko adsorbentu efektivitāti un adsorbcijas kapacitāti lielā mērā nosaka izejvielu kompozīcija, modificējošo (poras veidojošo) piedevu klātbūtne, termiskās apstrādes apstākḷi, tai skaitā arī atmosfēras vides raksturs krāsnī, porainība, poru izmēri un forma, adsorbenta dzeta potenciāls un sorbcijas vides $\mathrm{pH}$. Visi šie faktori ietekmē iegūtā adsorbenta īpatnējās virsmas lielumu, virsmas lādiṇa veidošanos, kā arī tā mehāniskās īpašỉbas. Poru diametri nosaka to jonu uz molekulu izmērus, kuri spēs difundēt porās. Īpatnējās virsmas lielums nosaka jonu vai molekulu daudzumu, kas var tikt adsorbēts uz adsorbenta virsmas. Virsmas lādin,š, kas tiek raksturots ar dzeta potenciāla palīdzību, savukārt nosaka, kādus savienojumus no elektroksīmiskā viedokḷa - katjonus, anjonus, nelādētas molekulas - adsorbentam ir lielāka tieksme adsorbēt. Šo īpašību kopums padara keramiskos adsorbentus par selektīviem materiāliem ar potenciāli augstu adsorbcijas kapacitāti, kas varētu tikt pielāgoti konkrētu savienojumu grupu adsorbēšanai. Klasiskajā keramikas tehnoloǵijā ir labi zināms, ka, paaugstinot keramikas materiālu apdedzināšanas temperatūru, to porainība un materiāla īpatnējā virsma samazinās, un tātad samazinās arī keramikas materiāla iespējamā sorbcijas spēja. Mūsdienās ir zināmi daudzi paṇēmieni kā palielināt apdedzināmā materiāla porainību. Visbiežāk tiek izmantotas organiskas izcelsmes materiālu piedevas, kas bieži ir dažādu ražošanas nozaru blakus produkti vai atkritumi, piemēram, koksnes skaidas, kafijas biezumi, salmi, graudu sēnalas, papīrs, u. c. Nemot vērā konkrēto izmantojamo mālu sastāvu un īpašības, iespējams izvēlēties konkrētu izejvielu maisījuma sastāvu, keramikas apdedzināšanas temperatūru, temperatūras celšanas ātrumu, lai iegūtu materiālu ar iespējami lielāko porainību un īpatnējo virsmu, kas ir svarīgs faktors sorbcijas procesos. Poraina mālu keramika var tikt iegūta gan granulu, gan membrānu veidā.

Potenciālo keramikas sorbentu iegūšanai izmanto gan dažādu atradṇu devona, gan dažādu atradṇu kvartāra māli ar atšksirīgu k̦īmisko un granulometrisko sastāvu [9], [10]. No devona māliem izmanto Liepas, Tūjas, Kupravas un Planču atradṇu mālus, bet no kvartāra māliem 
Progresa, Lažas, Prometeja un Šḷūcenieku atradṇu mālus. Visu izmantoto mālu kopīgā īpašìba ir tā, ka tie pēc sava mineralogiskā satura ir illīta tipa hidrovizlu māli, kuros ir arī neliels daudzums kaolinīta. Abu grupu mālu galvenā atšķirība ir sārmzemju metālu oksīdu saturs tajos. Sārmzemju oksīdi mālos galvenokārt ir saistīti karbonātu veidā kā kalcīts $\left(\mathrm{CaCO}_{3}\right)$ vai dolomīts $\left(\mathrm{CaCO}_{3} \cdot \mathrm{MgCO}_{3}\right)$, tāpēc kvartāra mālus arī sauc par karbonātus saturošiem māliem.

Keramikas paraugi gatavoti no plastiskām mālu masām, un apdedzinātu materiālu porainības palielināšanai tiek izmantotas dažādas organiskas dabas izdegošas piedevas: zāǵu skaidas ( $\varnothing \leq 2 \mathrm{~mm})$, sasmalcināti salmi, biodīzel̦degvielas ražošanas atkritums - glicerīns. Porainas mālu keramikas filtrēšanas iespēju pētīšanai izgatavoti paraugi ar koncentrētas suspensijas liešanas paṇēmienu, kur poras veidojas k̦īmiskas reakcijas ceḷā, ūdens klātbūtnē izdaloties gāzveida ūdeṇradim.

\section{A. Devona mālu keramikas granulas}

Keramikas granulu iegūšanai izmantoti galvenokārt devona Liepas un Kupravas atradṇu māli, bet atsevišksi pētījumi veikti arī ar Tūjas un Planču atradṇu devona māliem. Gan Liepas, gan Kupravas māli ir ar diezgan nevienmērīgu ķīmisko un mineralogisko sastāvu. Tāpēc konkrētajā pētījumā izmantoto mālu ķīmiskie sastāvi doti IV. tabulā.

Pētījumos izmantoto devona mālu k̦īmiskie sastāvi ir visai atšksirīgi [4], un tāpat atšķirīgi ir arī to granulometriskie sastāvi, t. i., smilšu, putekḷu

IV. tabula

Pētījumos izmantoto devona mālu k̦īmiskie sastāvi

\begin{tabular}{|c|c|c|c|c|}
\hline \multirow{2}{*}{ Mālu sastāvs } & \multicolumn{4}{|c|}{ Pētījumos izmantoto mālu sastāvs, masas\% } \\
\hline & Liepa & Kuprava & Tūja & Planči \\
\hline $\mathrm{SiO}_{2}$ & 62,19 & 53,78 & 66,25 & 76,31 \\
\hline $\mathrm{Al}_{2} \mathrm{O}_{3}$ & 15,45 & 18,80 & 12,60 & 11,63 \\
\hline $\mathrm{Fe}_{2} \mathrm{O}_{3}$ & 7,15 & 9,07 & 5,40 & 2,93 \\
\hline $\mathrm{CaO}$ & 0.83 & 1,95 & 2,56 & 1,12 \\
\hline $\mathrm{MgO}$ & 1,32 & 3,44 & 2,61 & 1,03 \\
\hline $\mathrm{TiO}_{2}$ & 1,92 & 0,65 & 0,65 & 0,24 \\
\hline $\mathrm{Na}_{2} \mathrm{O}$ & 0,09 & 0,00 & 0,25 & 0,00 \\
\hline $\mathrm{K}_{2} \mathrm{O}$ & 4,12 & 5,10 & 3,18 & 2,61 \\
\hline Karsēšanas zudumi $400^{\circ} \mathrm{C}$ & 2,04 & 2,14 & 2,08 & 0,95 \\
\hline $\begin{array}{c}\text { Karsēšanas zudumi } \\
1000^{\circ} \mathrm{C}\end{array}$ & 4,12 & 4,54 & 3,80 & 2,13 \\
\hline Kopā & 99,23 & 99,47 & 99,38 & 98,95 \\
\hline
\end{tabular}


(aleirītu) un mālu frakciju daudzums konkrētajos dabīgajos mālos. Palielināts smilšu frakcijas saturs ir Liepas, Tūjas un Planču mālos. N̦emot vērā šo mālu līdzīgo mineralogisko sastāvu, abi pēdējie mālus raksturojošie parametri - k̦īmiskais sastāvs un granulometriskais sastāvs - arī stipri ietekmē no māliem iegūstamo keramikas materiālu īpašības.

Mālu keramikas sorbcijas īpašību pētǐšanai konkrētajiem izžāvētajiem māliem pievienoja 3 masas\% sausu zāğu skaidu ar diametru $\leq 2 \mathrm{~mm}$. No plastiskas masas izgatavotas granulas, kuras pēc izžāvēšanas apdedzinātas dažādās temperatūrās $700-1100{ }^{\circ} \mathrm{C}$ intervālā, atkarībā no pašu mālu rakstura. Iegūtajām keramikas granulām noteica kristālisko fāžu sastāvu (rentgena staru difraktometrija - difraktometrs Rigaku Ultima +, Japāna), poru struktūra (dzīvsudraba porozimetrija - PoreMaster Quantachrome Instrument, ASV) un slāpekḷa absorbcija - (BET Nova 1200e, Quantachrome Instrument, ASV), materiāla daḷinu virsmas lādinš jeb dzeta potenciāls (Nano Zetasizer, Malvern Instrument, Lielbritānija), granulu-ūdens immersijas pH (METLER TOLEDO Seven Multi, Šveice). Iegūtajām granulām noteica sorbcijas spēju no piesārn,ota šksīduma attiecībā uz trīs veidu piesārņojošām neorganiskām vielām: molekulāram savienojumam jodam, jonam ar pozitīvu lādiṇu (amonija jons) un jonam ar negatīvu lādinu (dihromāta jons).

Visiem 800-1050 ${ }^{\circ} \mathrm{C}$ temperatūrā apdedzinātiem devona māliem rentgena staru fāžu analīze uzrāda vienādas kristāliskās fāzes. Vienīgā atšksirība ir hematīts, kas parādās tikai to mālu keramikas paraugos, kuru dzelzs oksīda saturs ir lielāks par $5 \%$ un kas apdedzināti temperatūrās virs $1000^{\circ} \mathrm{C}$, t. i., Liepas un Kupravas mālu keramikas paraugos.

No sorbcijas viedoklı svarīga ir vides $\mathrm{pH}$ vērtība pēc apdedzināto granulu iemērkšanas ūdenī. Noteiktās pH vērtības dažādās temperatūrās apdedzinātām devona mālu granulām apkopotas V. tabulā. Kā liecina tabulā apkopotie rezultāti, iemērcot pētīto devona mālu granulas ūdenī, pH samazinās, paaugstinot to apdedzināšanas temperatūru. Kupravas

V. tabula

Dažādās temperatūrās apdedzinātu devona mālu granulu $\mathrm{pH}$ ūdens vidē

\begin{tabular}{ccccc}
\hline \multirow{2}{*}{ Izejvielas } & \multicolumn{4}{c}{ Apdedzināšanas temperatūras, ${ }^{\circ} \mathrm{C}$} \\
\cline { 2 - 5 } & $800^{\circ} \mathrm{C}$ & $900^{\circ} \mathrm{C}$ & $1000^{\circ} \mathrm{C}$ & $1050^{\circ} \mathrm{C}$ \\
\hline Liepas māls + 3\% zāǵu skaidas & 7,2 & 7,5 & 7,2 & 6,6 \\
\hline Kupravas māls + 3\% zāǵu skaidas & 10,2 & 9,9 & 7,5 & 6,3 \\
\hline Kupravas māls + 2 \% glicerīns & 11,3 & 10,8 & 7,5 & 6,5 \\
\hline Planču māls + 3\% zāǵu skaidas & 6,2 & 6,2 & 5,8 & 5,7 \\
\hline Tūjas māls* & - & 7,6 & 7,2 & 6,3 \\
\hline
\end{tabular}

* - poras veidojas ḳīmiskā reakcijā starp ūdeni un alumīnija pulveri. 
māli ir mazkarbonātu māli, jo tajos, atškirīībā no Liepas, Planču un Tūjas māliem, rentgena fāžu analīze uzrāda dolomīta vai kalcīta klātbūtni. Tāpēc šo mālu granulas, kas apdedzinātas $800{ }^{\circ} \mathrm{C}$ un $900{ }^{\circ} \mathrm{C}$ temperatūrās, ūdenī dod bāzisku vidi. Tas saistīts ar karbonātu sadalīšanos šajās temperatūrās un $\mathrm{CaO}$ vai $\mathrm{MgO}$ saglabāšanos nesaistītā veidā.

Joda adsorbcija uz dažādās temperatūrās apdedzinātu devona mālu granulām notiek līdzīgi - visstraujāk tā notiek pirmajās divās dienās, bet pēc tam adsorbcijas ātrums mainās maz. 17. att. parādīta joda adsorbcija uz dažādās temperatūrās apdedzinātām Kupravas mālu granulām [11].

Vislielākā joda daudzuma adsorbcija ir uz granulām, kas apdedzinātas līdz $900{ }^{\circ} \mathrm{C}$ temperatūrai. Augstākās temperatūrās apdedzinātu granulu joda adsorbcijas spēja samazinās, tas ir saistīts ar adsorbenta porainības samazināšanos keramikas saḳepšanas rezultātā. Joda adsorbcijas izmaiṇu vislabāk raksturo materiāla poru īpatnējais virsmas laukums, kas noteikts gan ar dzīvsudraba porozimetrijas, gan slāpekḷa adsorbcijas metodēm un apkopots VI. tabulā. Lielākais īpatnējās virsmas laukums ir zemākajās, t. i., $700{ }^{\circ} \mathrm{C}$ un $800{ }^{\circ} \mathrm{C}$, temperatūrās apdedzinātām granulām. $700{ }^{\circ} \mathrm{C}$ temperatūrā apdedzinātas granulas sorbcijai parasti netika izmantotas, jo tās ūdenī viegli sadalās nepietiekošas saḳepšanas dēḷ.

Amonija katjonu adsorbcija ir lielā mērā jutīga pret vides pH [12]. Bāziskā vidē ap amonija joniem veidojas hidroksīda anjonu apvalks, kas apgrūtina to kustīgumu šķīdumā un difūziju granulu porās. Labākie katjonu adsorbcijas rezultāti iegūti ar bezkarbonātu Liepas mālu granulām, kur vides pH ir vāji skābs. Lielākā amonija katjona adsorbcijas spēja ir $800{ }^{\circ} \mathrm{C}$ temperatūrā apdedzinātām granulām, un tā ir 0,35 mg amonija jona uz 1 g keramikas granulu. Amonija jonu sorbcija notiek loti lēni un maksimumu sasniedz pēc divām nedēḷām. Dihromāta sorbcija uz devona mālu keramikas granulām ir neliela. Slāpekḷa adsorbcijas (BET) metodes rezultāti (poru īpatnējās virsmas laukums, poru tilpums, poru

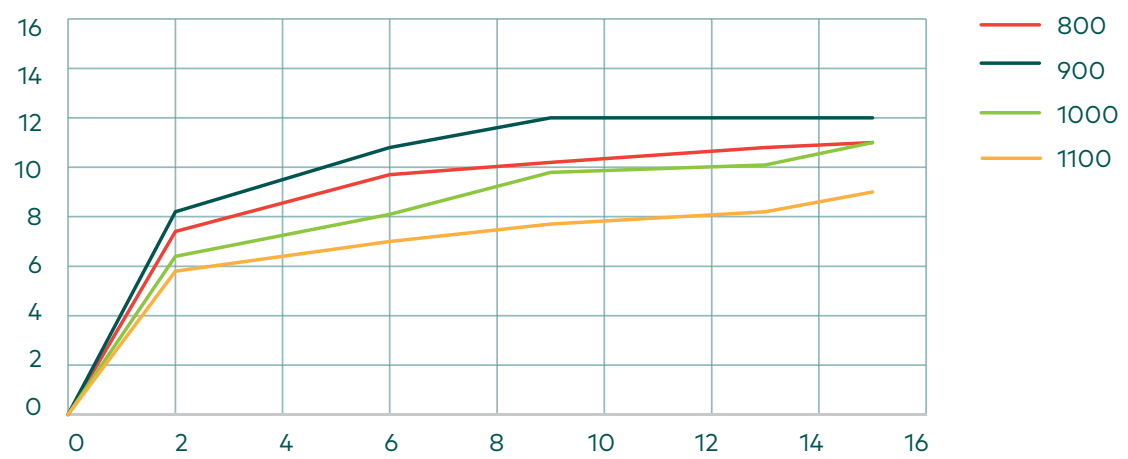

17. att. Joda adsorbcija uz dažādās temperatūrās apdedzinātām Kupravas mālu granulām. 
rādiuss) raksturo ne vien keramikas materiālu sorbcijas īpašības, bet arī l̦auj analizēt keramikas materiālu saksepšanas procesus, optimizēt keramikas apdedzināšanu un iegūt materiālus ar nepieciešamajām īpašībām. Granulu īpatnējās virsmas laukuma atkarību no apdedzināšanas temperatūras ietekmē arī izejvielu (mālu) sākotnējais granulometriskais sastāvs - jo lielāks smilšu frakcijas saturs, jo mazāks poru īpatnējās virsmas laukums. Keramikas granulu porainības palielināšanai kopā ar koksnes skaidām Kupravas māliem pievienoja 5 \% dīzeḷdegvielas ražošanas atkritumu - glicerīnu, un sorbcijas spējas palielināšanai $700{ }^{\circ} \mathrm{C}$ un $800^{\circ} \mathrm{C}$ temperatūrās apdedzinātās granulas apstarotas ar elektroniem. Elektronu enerǵija bija $5 \mathrm{MeV}$, un absorbētais daudzums bija 10 MGy [13], [14]. Dzīvsudraba porozimetrijas mērījumu rezultāti liecina, ka glicerīna pievienošana māliem kopā ar koksnes skaidām izmaina keramikas poru struktūru atkarībā no apdedzināšanas temperatūras, t. i., palielina keramikas porainību, bet jo sevišķi ỉpatnējās virsmas laukumu (VII. tabula). Ievērojamais virsmas laukuma palielinājums liecina par mazākā izmēra poru daudzuma palielināšanos, kas ir svarīgs faktors sorbcijas spējas palielināšanai. Paraugu sorbcijas spēja palielinās apmēram 7 reizes gadījumā, kad mālam kopā ar zāǵu skaidām pievienots arī 5 \% glicerīna. Apstarošana ar paātrinātajiem elektroniem neizmaina materiālu sorbcijas spēju attiecībā uz organiskiem savienojumiem.

Ievērojamais virsmas laukuma palielinājums liecina par mazākā izmēra poru daudzuma palielināšanos, kas ir svarīgs faktors sorbcijas

Devona mālu granulu īpatnējās virsmas laukums

\begin{tabular}{|c|c|c|c|}
\hline Devona māli & $\begin{array}{c}\text { Granulu } \\
\text { apdedzināšanas } \\
\text { temperatūra, }{ }^{\circ} \mathrm{C}\end{array}$ & $\begin{array}{c}\text { Īpatnējās virsmas laukums ar } \\
\text { dzīvsudraba porozimetriju, } \\
\mathrm{m}^{2} \cdot \mathrm{g}^{-1}\end{array}$ & $\begin{array}{l}\text { T̄patnējās virsmas } \\
\text { laukums ar slāpek!̣a } \\
\text { adsorbciju, } \mathrm{m}^{2} \cdot \mathrm{g}^{-1}\end{array}$ \\
\hline \multirow{4}{*}{ Liepa } & 700 & 17,80 & 26,94 \\
\hline & 800 & 20,21 & 20,69 \\
\hline & 900 & 14,18 & 2,09 \\
\hline & 1050 & 3,01 & 0,35 \\
\hline \multirow{4}{*}{ Planči } & 700 & 9,61 & 15,80 \\
\hline & 800 & 9,20 & 13,94 \\
\hline & 900 & 2,49 & 1,73 \\
\hline & 1050 & 0,22 & 0,06 \\
\hline \multirow{2}{*}{ Kuprava } & 800 & 13,94 & 14,98 \\
\hline & 900 & 6,20 & 8,39 \\
\hline
\end{tabular}


Kupravas mālu keramikas porainība un īpatnējās virsmas laukums

\begin{tabular}{ccccc}
\hline \multirow{2}{*}{$\begin{array}{c}\text { Apdedzināšanas } \\
\text { temperatūra, }{ }^{\circ} \mathrm{C}\end{array}$} & \multicolumn{2}{c}{ Porainība, \% } & \multicolumn{2}{c}{$\begin{array}{c}\text { Īpatnējais virsmas laukums, } \\
\mathrm{cm}^{2} \cdot \mathbf{g}^{-1}\end{array}$} \\
\cline { 2 - 5 } & Bez glicerīna & Ar glicerīnu & Bez glicerīna & Ar glicerīnu \\
\hline 800 & 23,47 & 26,01 & 11,36 & 24,12 \\
900 & 17,57 & 31,73 & 6,91 & 16,27 \\
\hline
\end{tabular}

spējas palielināšanai. Paraugu sorbcijas spēja palielinās apmēram 7 reizes gadījumā, kad mālam kopā ar zāǵu skaidām pievienots arī 5 \% glicerīna.

Apdedzinātu Kupravas mālu granulu virsmas aktivēšanai izmantots ZnO nanoizmēru daḷiṇu pārklājums. ZnO nanodaḷiṇas iegūst no cinka acetāta šḳīduma. Materiālu fotokatalītiskā aktivitāte analizēta attiecībā uz etiķskābes sadalīšanu, apstarojot to ar redzamo gaismu ar viḷna garumu $460 \mathrm{~nm}$. Paraugu fotokatalītiskā aktivitāte palielinās, paaugstinot mālu granulu apdedzināšanas temperatūru, t. i., samazinoties paraugu porainībai (VIII. tabula).

Devona Tūjas māls izmantots keramisku filtru izgatavošanai (Arnis Zembaks, Augsti poraina Tūjas mālu keramika filtrēšanas vajadzībām, maǵistra darbs, 2015. g.). Poras veidojas k̦īmiskas reakcijas rezultātā starp metāliska alumīnija pulveri un ūdeni bāziskā vidē koncentrētā mālu suspensijā. Poru struktūra materiālā izveidojas suspensijas sacietēšanas un žūšanas rezultātā. Izveidotas 2 paraugu sērijas: viena no Tūjas atradnes māliem, otra - no šiem māliem ar $15 \%$ talka piedevu. Sastāvu izvēles mērḳis bija palielināt to porainību un ūdens caurlaidību. Abu sēriju paraugu ūdens uzsūkšanas spēja atkarībā no apdedzināšanas temperatūras apkopota 18. att. Paraugiem bez talka piedevas tilpuma masa ir $0,81-0,91 \mathrm{~g} \cdot \mathrm{cm}^{-3}$, bet paraugiem ar talka piedevu tas samazinās līdz $0,72-0,77 \mathrm{~g} \cdot \mathrm{cm}^{-3}$, atkarībā no apdedzināšanas temperatūras. Ūdens caurtece mainās robežās no $600 \mathrm{~L} \cdot \mathrm{m}^{-2} \cdot \mathrm{h}^{-1} \mathrm{līdz} 1000 \mathrm{~L} \cdot \mathrm{m}^{-2} \cdot \mathrm{h}^{-1}$. Filtriem vienlaicīgi piemīt arī sorbcijas spēja. Filtrējot jūras ūdeni, kas satur izšķīdušus sāḷus, ūdens elektrovadītspēja (konduktometrs METTLER TOLEDO SevenCompact) pēc filtrēšanas samazinās par $10 \%$.

VIII. tabula

Fotokatalītiski sadalītas etiḳskābes daudzums

\begin{tabular}{ccc}
\hline Apdedzināšanas temperatura, ${ }^{\circ} \mathrm{C}$ & \multicolumn{2}{c}{ Sadalītais etiḳskābes daudzums, $\mathbf{m g} \cdot \mathbf{g}-\mathbf{1}$} \\
\cline { 2 - 3 } & Bez glicerīna & Ar glicerīnu \\
\hline 800 & 105,69 & 90,04 \\
900 & 128,93 & 121,42 \\
\hline
\end{tabular}




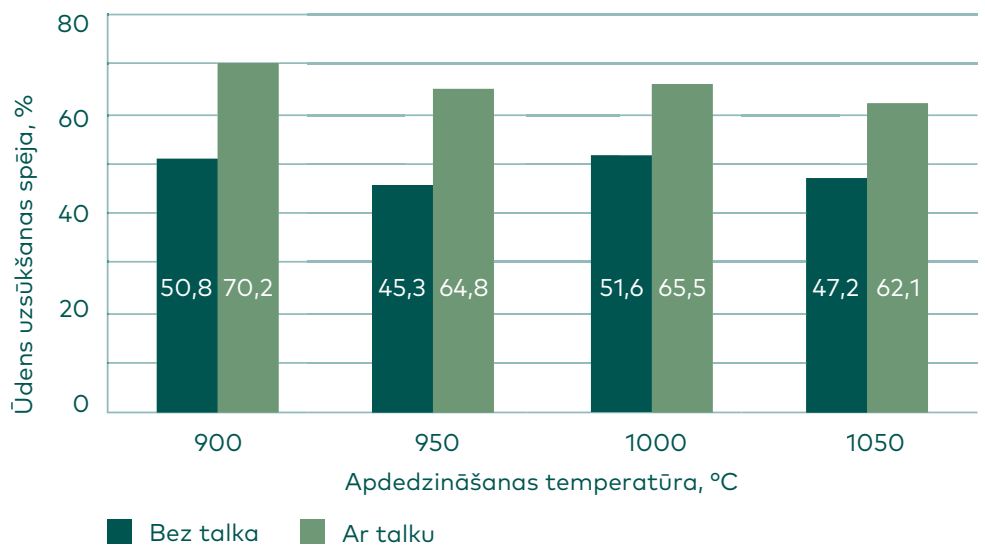

18. att. Keramisko filtru ūdens uzsūkšanas spēja.

\section{B. Kvartāra mālu keramikas granulas}

Keramikas granulu iegūšanai izmantoti 4 atšķirīga granulometriskā sastāva māli. Progresa (Ānes) un Šḷūcenieku māli ir liesi ar lielu smilšu frakcijas saturu, savukārt Prometeja un Lažas māli ir vieni no treknākajiem Latvijas māliem ar ḷoti lielu mālu frakcijas saturu, kas pārsniedz 82 \%. Progresa un Šḷuccenieku māliem ir raksturīgs arī liels putekḷu frakcijas saturs $45-47 \%$.

IX. tabula

Izmantoto kvartāra mālu kīimiskais sastāvs

\begin{tabular}{ccccc}
\hline \multirow{2}{*}{ Mālu sastāvs } & \multicolumn{4}{c}{ Mālu ḳimiskais sastāvs, masas\% } \\
\cline { 2 - 5 } & 51,82 & 49,16 & 45,95 & 46,48 \\
$\mathrm{SiO}_{2}$ & 14,69 & 13,72 & 17,07 & 18,74 \\
$\mathrm{Al}_{2} \mathrm{O}_{3}$ & 5,47 & 3,15 & 6,78 & 7,06 \\
$\mathrm{Fe}_{2} \mathrm{O}_{3}$ & 8,27 & 11,18 & 5,95 & 6,62 \\
$\mathrm{CaO}$ & 2,52 & 3,35 & 3,86 & 3,25 \\
$\mathrm{MgO}$ & 0,59 & 0,55 & 0,58 & 0,59 \\
$\mathrm{TiO}_{2}$ & 0,53 & 0,80 & 0,17 & 0,41 \\
$\mathrm{Na}_{2} \mathrm{O}$ & 3,35 & 2,65 & 3,93 & 3,62 \\
$\mathrm{~K}_{2} \mathrm{O}$ & 1,42 & 1,05 & 4,52 & 3,20 \\
Masas zudumi $400^{\circ} \mathrm{C}$ & 10,92 & 13,82 & 9,96 & 9,64 \\
\hline Masas zudumi $1000^{\circ} \mathrm{C}$ & 99,58 & 99,43 & 98,77 & 99,61 \\
\hline Kopā & & & & \\
\hline
\end{tabular}


Izmantoto kvartāra mālu granulometriskais sastāvs

\begin{tabular}{ccccc}
\hline \multirow{2}{*}{ Mālu frakcijas } & \multicolumn{4}{c}{ Frakcijas daudzums, masas\% } \\
\cline { 2 - 5 } & Progress (Āne) & Š|̣̄cenieki & Prometejs & Laža \\
\hline Smiltis $\varnothing>0,05 \mathrm{~mm}$ & 8,45 & 8,5 & 1,8 & 3,39 \\
Putek|̣i $\varnothing 0,05-0,005 \mathrm{~mm}$ & 46,88 & 45,5 & 13,3 & 14,31 \\
Mālu frakcija $\varnothing<0,005 \mathrm{~mm}$ & 44,67 & 46,0 & 84,9 & 82,30 \\
\hline
\end{tabular}

Atšķirīgais izmantoto kvartāra mālu ķīmiskais (IX. tabula) un granulometriskais (X. tabula) sastāvs l̦auj jau iepriekš paredzēt atšķiirīgu porainību iegūstamajām keramikas granulām, kas ir l̦oti svarīga īpašība dažāda pielietojuma sorbentiem. Visos gadījumos iegūstamo materiālu porainības palielināšanai māliem pievienots 3 masas\% koksnes skaidu.

Kvartāra mālu mineralogiskais sastāvs mālu minerālu ziṇā līdzīgs devona māliem - illīts un kaolinīts, bet kā norāda k,īmiskais sastāvs kvartāra mālos ir sārmzemju metālu karbonātu - kalcīta un dolomīta piemaisījumi. Vislielākais karbonātu saturs ir Šḹcenieku un Progresa (Ānes) mālos. Karbonātu klātbūtne mālos ietekmē arī iegūstamās keramikas porainību. XI. tabulā parādīts ar dzīvsudraba porozimetrijas metodi (PoreMaster, Quantachrome Instrument) noteiktās porainības un īpatnējās virsmas laukuma salīdzinājums $800-1100{ }^{\circ} \mathrm{C}$ temperatūrās apdedzinātām kvartāra mālu keramikas granulām [15], [16]. Prometeja māliem bez koksnes skaidām pievienots arī 2 \% glicerīna.

Ar dzīvsudraba porozimetrijas metodi noteiktā porainība atkarībā no apdedzināšanas temperatūras mainās ḷoti maz, samazināšanās ir tikai temperatūrās virs $1000{ }^{\circ} \mathrm{C}$ atkarībā no mālu granulometriskā sastāva.

XI. tabula

Kvartāra mālu keramikas granulu dzīvsudraba porozimetrijas rezultāti

\begin{tabular}{ccccccccc}
\hline \multirow{2}{*}{ Mālu atradne } & \multicolumn{5}{c}{ Porainība, \% } & \multicolumn{5}{c}{ Ipatnējais virsmas laukums, $\mathrm{m}^{2} \cdot \mathrm{g}^{-1}$} \\
\cline { 2 - 9 } & $\mathbf{8 0 0}{ }^{\circ} \mathrm{C}$ & $900^{\circ} \mathrm{C}$ & $1000^{\circ} \mathrm{C}$ & $1100^{\circ} \mathrm{C}$ & $800^{\circ} \mathrm{C}$ & $900^{\circ} \mathrm{C}$ & $1000^{\circ} \mathrm{C}$ & $1100^{\circ} \mathrm{C}$ \\
\hline Progress (Āne) & 21,81 & 20,50 & $\begin{array}{c}20,06 \\
\left(1050{ }^{\circ} \mathrm{C}\right)\end{array}$ & - & 9,32 & 3,63 & $\begin{array}{c}1,56 \\
\left(1050{ }^{\circ} \mathrm{C}\right)\end{array}$ & - \\
\hline Šlūcenieki & 22,27 & 22,53 & 23,00 & 22,15 & 3,29 & 2,84 & 1,68 & 1,75 \\
\hline Prometejs & 26,69 & 22,64 & 22,07 & 11,19 & 12,35 & 4,88 & 3,81 & 3,79 \\
\hline $\begin{array}{c}\text { Prometejs + } \\
2 \% \text { glicerīns }\end{array}$ & 26,70 & 22,70 & 19,10 & 6,80 & 18,90 & 3,90 & 3,80 & 1,50 \\
\hline Laža & 14,15 & 12,04 & $\begin{array}{c}4,79 \\
\left(1050{ }^{\circ} \mathrm{C}\right)\end{array}$ & - & 16,21 & 6,07 & $\begin{array}{c}2,67 \\
\left(1050{ }^{\circ} \mathrm{C}\right)\end{array}$ & - \\
\hline
\end{tabular}


Faktiski porainības vērtības, kas iegūtas ar šo metodi, ir ievērojami samazinātas, jo raksturo diametru kanāliem, kas savieno poras savā starpā. Daudz noderīgāks poru struktūras raksturojums ir poru īpatnējās virsmas laukums. Šis lielums raksturo virsmu, kas ir izmantojama sorbcijas procesos. Vēl noderīgāka ir poru izmēru histogramma, kas uzrāda katra izmēra poru tilpumu. 19. att. parādītas poru tilpumu histogrammas $800{ }^{\circ} \mathrm{C}$ temperatūrās apdedzinātām Șlūcenieku un Prometeja mālu granulām.

Histogrammas uzskatāmi parāda poru struktūru atšķirību abu veidu granulām un izskaidro īpatnējās virsmas laukuma atšķirības. Lielāku virsmas laukumu nodrošina mazāka izmēra poras $0,01-0,1 \mu \mathrm{m}$, kuru tilpums Prometeja mālu granulās ir ievērojami lielāks nekā Ș̣̂ucenieku mālu granulās. Poru struktūras analīze pēc dzīvsudraba porozimetrijas rezultātiem uzrāda būtiskas lieso un trekno mālu granulu atšksiīibas. Treknajos mālos (Lažas un Prometeja atradnes) granulās ir viens

a

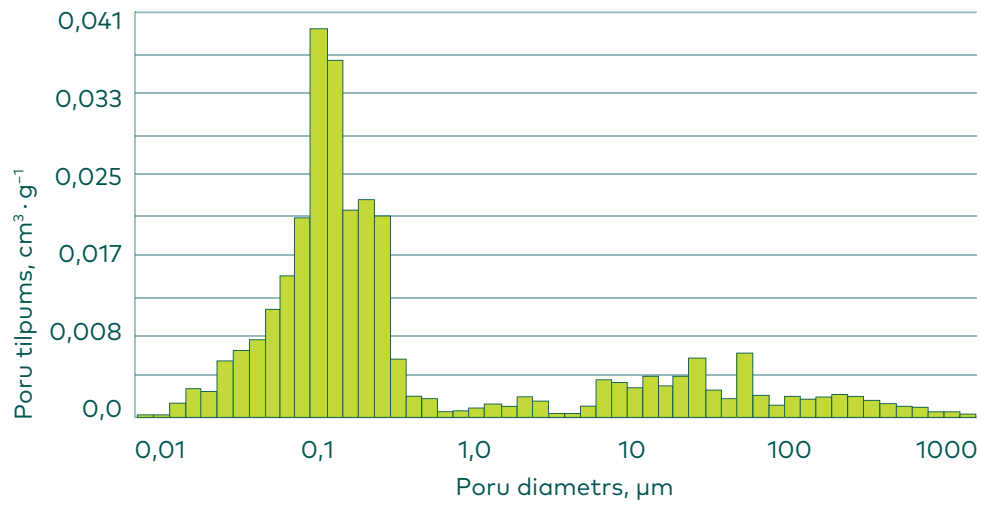

b

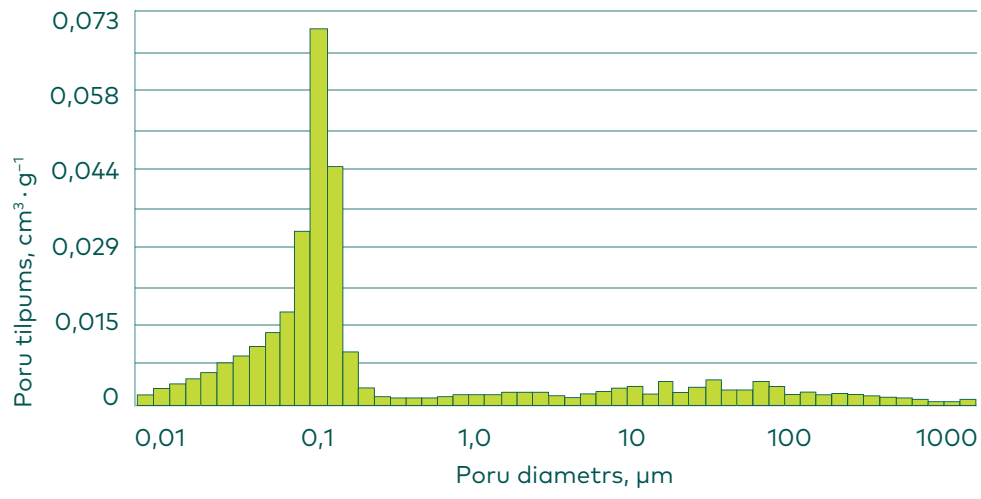

19. att. Poru tilpuma histogrammas $800^{\circ} \mathrm{C}$ temperatūrā apdedzinātām granulām: a - Šḷūcenieku māli; b - Prometeja māli. 
dominējošais poru izmērs, kurš, paaugstinot apdedzināšanas temperatūru līdz $900{ }^{\circ} \mathrm{C}$, pārvietojas lielākā izmēra poru virzienā. Savukārt granulās, kuras apdedzinātas $1050-1100{ }^{\circ} \mathrm{C}$ temperatūrā, izzūd šis dominējošais poru izmērs un parādās poras nanometru diapazonā. Visā apdedzināšanas temperatūru diapazonā ievērojami samazinās poru tilpums. Salīdzinot ar Lažas un Prometeja mālu granulām, Progresa un Šḷūcenieku mālu granulās poru tilpums ir neliels ap $0,90 \mathrm{~cm}^{3} \cdot \mathrm{g}^{-1}$, un tas samazinās, paaugstinot apdedzināšanas temperatūru līdz apmēram $0,35 \mathrm{~cm}^{3} \cdot \mathrm{g}^{-1}$.

Poru izmēri un poru īpatnējās virsmas laukums ir noteicošie faktori fizikālās adsorbcijas gadījumā, kad adsorbāts saistās uz virsmas parasti monomolekulāra slān,a veidā. Savukārt k̦īmiskās sorbcijas gadījumā bez minētiem lielumiem procesu raksturo arī sorbenta virsmas lādiṇ̌ un vides pH. Šie lielumi pētītajiem māliem apkopoti XII. tabulā. Rezultāti liecina, ka lieso mālu ar lielāku karbonātu saturu granulas, neatkarīgi no to apdedzināšanas temperatūras ūdenī veido bāzisku vidi. Bāziskums samazinās, paaugstinot granulu apdedzināšanas temperatūru. Savukārt trekno Prometeja mālu ar mazāko karbonātu saturu granulas jau pēc apdedzināšanas $900{ }^{\circ} \mathrm{C}$ temperatūrā ūdenī veido neitrālu vai vāji skābu vidi. Treknajiem Lažas māliem ar nedaudz lielāku karbonātu saturu tikai $1100{ }^{\circ} \mathrm{C}$ temperatūrā apdedzinātas granulas ūdenī veido vāji skābu vidi.

Molekulārā savienojuma joda sorbcijas rezultāti rāda, ka sorbcijas ātrums un adsorbētā joda daudzums uz kvartāra mālu keramikas granulām ir līdzīgi abos liesajos un abos treknajos mālos. Salīdzinot ar devona Liepas, Planču un Kupravas mālu granulām, sorbcijas ātrums ir ievērojami mazāks. Ja devona mālu granulas adsorbēja visu šḳīdumā esošo jodu dažās stundās, tad kvartāra mālu granulu gadỉjumā šis process turpinājās vairākas dienas. $800^{\circ} \mathrm{C}$ un $900^{\circ} \mathrm{C}$ temperatūrās apdedzinātās trekno mālu granulas adsorbēja visu šḳīdumā esošo jodu 3 dienās, bet

XII. tabula

Kvartāra mālu keramikas granulu vides $\mathrm{pH}$ un virsmas lādiṇš

\begin{tabular}{|c|c|c|c|c|c|c|c|c|}
\hline \multirow{2}{*}{ Mālu atradne } & \multicolumn{4}{|c|}{ Vides $\mathrm{pH}$} & \multicolumn{4}{|c|}{ Virsmas lādiṇš (dzeta potenciāls) } \\
\hline & $800^{\circ} \mathrm{C}$ & $900^{\circ} \mathrm{C}$ & $1000^{\circ} \mathrm{C}$ & $1100^{\circ} \mathrm{C}$ & $800^{\circ} \mathrm{C}$ & $900^{\circ} \mathrm{C}$ & $1000^{\circ} \mathrm{C}$ & $1100^{\circ} \mathrm{C}$ \\
\hline \multirow[t]{2}{*}{ Progress (Āne) } & 10,6 & 10,7 & 9,8 & - & $-20,9$ & $-23,2$ & $-30,8$ & - \\
\hline & & & $\left(1050^{\circ} \mathrm{C}\right)$ & & & & $\left(1050^{\circ} \mathrm{C}\right)$ & \\
\hline Š|ūcenieki & 11,2 & 11,5 & 10,7 & 9,7 & $-11,5$ & $-15,4$ & $-18,9$ & $-20,4$ \\
\hline Prometejs & 9,8 & 7,0 & 6,7 & 6,4 & $-22,5$ & $-25,3$ & $-30,6$ & $-22,0$ \\
\hline $\begin{array}{c}\text { Prometejs + } \\
\text { glicerīns }\end{array}$ & 10,3 & 7,1 & 7,1 & 6,8 & $-23,0$ & $-27,5$ & $-33,7$ & $-24,7$ \\
\hline Laža & 9,8 & 10,5 & 8,6 & 5,8 & $-21,8$ & $-23,2$ & $-28,4$ & $-20,1$ \\
\hline
\end{tabular}


lieso mālu granulas tikai 6 dienās. $1000-1100{ }^{\circ} \mathrm{C}$ temperatūrās apdedzinātas granulas 2 nedēlu laikā bija adsorbējušas tikai ap $80 \%$ no šķīdumā esošā joda. Izvērtējot šos rezultātus saistībā ar poru īpatnējo virsmas laukumu (XI. tabula), ir redzams, ka šīm granulām ir arī ievērojami mazāks īpatnējās virsmas laukums. Amonija un dihromāta jonu sorbcijas kapacitāte ir niecīga un sasniedz tikai attiecīgi $0,35 \mathrm{mg} \cdot \mathrm{g}^{-1}$ un 3,2-4,3 mg.g ${ }^{-1}$ vairāku dienu laikā.

Sadarbībā ar LU Bioloǵijas fakultātes Mikrobiologijas katedras un Mikrobiologijas institūta zinātniekiem pētīta gan devona, gan kvartāra mālu granulu, gan dažādas porainības un tilpuma masas (ūdenī peldošs vai grimstošs) keramzīta noderība mikroorganismu imobilizācijai ar tai sekojošu šo komplekso materiālu izmantošanu dažādu objektu (ūdens, augsne) attīī̌šanai no piesārnojuma [17], [18]. Mikroorganismu imobilizācijai noderīgas tikai tādas granulas, kuras ūdens vidē uzrāda vāji skābu vai neitrālu reakciju.

\section{Pateicības}

Pētījumi par Latvijas māliem un to izmantošanu veikti ar Latvijas Izglītības Ministrijas finansēto Valsts pētījumu programmas Nr. Nr.2014. 10-4/VPP-5 Nr. V7883. 1.4. apakšprojekts "Energotaupīgas augsti poraina keramzīta iegūšanas tehnologijas no Latvijas māliem" un Nr.2014.10-4/VPP-6/4 "Meža un zemes dzịlu resursu izpēte, ilgtspējīga izmantošana - jauni produkti un tehnologijas (ResProd)", 6. apakšprojekts "Zemes dzịlu resursu izpēte dabisko izejvielu dažādošanai un jaunu tehnologiiju izstrādei (GEO)" finansiālu atbalstu.

\section{LITERATŪRAS SARAKSTS}

[1] R. Švinka, L. Bīdermanis, A. Cimmers, V. Švinka, and S. Čertoks, "Comparable properties of some building materials," RTU zinātniskie raksti. Materiālzinātne un lietiškā kīimija, vol. 17, pp. 45-51, 2008.

[2] V. Švinka, A. Cimmers, S. Čertoks, R. Švinka, and L. Bīdermanis, "Poru struktūras veidošanās silikātu keramikas materiālos,” RTU zinātniskie raksti. Materiālzinātne un lietišḳā k̦īmija, vol. 19, pp. 100-108, 2009.

[3] V. Švinka, R. Švinka, L. Bīdermanis, A. Butlers, and S. Krebs, "Poraina celtniecības keramika bez izdegošām piedevām," RTU zinātniskie raksti. Materiālzinātne un lietišksā ḳīmija, vol. 19, pp. 114-121, 2009.

[4] V. Švinka, L. Bīdermanis, R. Švinka, L. Lindina, A. Cimmers, and I. Timma, "Termoḳīmiskas reakcijas mālu minerālos šūnu keramikas iegūšanai," RTU zinātniskie raksti. Materiālzinātne un lietišḳa k̦īmija, vol. 24, pp. 56-60, 2011. 
[5] L. Bīdermanis, V. Švinka, R. Švinka, I. Timma, L. Lindiṇa, and A. Cimmers, "Mālu izejvielu novērtējums šūnainās keramikas iegūšanai," RTU zinātniskie raksti. Materiālzinātne un lietišķā k̦īmija, vol. 19, pp. 93-99, 2009.

[6] V. Švinka, R. Švinka, L. Bīdermanis, I. Timma, and A. Cimmers, "Mālu izejvielas keramzīta ātrās apdedzināšanas tehnologijai," RTU zinātniskie raksti. Materiālzinātne un lietišķā k̦īmija, vol. 26, pp. 49-54, 2012.

[7] V. Švinka, R. Švinka. L. Dabare, A. Cimmers, L. Lindinga, and I. Timma, "Poraina silikātu keramika no Latvijas māliem un tās iespējamais pielietojums," Latvijas derīgie izrakteñi, jaunas tehnoloǵijas, materiāli un produkti, pp. 88-98, 2014.

[8] V. Švinka, L. Bīdermanis, A. Cimmers, and R. Švinka, "Keramzīta iegūšanas pan̄ēmiens," LV Patent LV14291 B, 20 May, 2011.

[9] R. Svinka, V. Svinka, and L. Dabare, "Porainu kvartāra mālu keramikas granulu sorbcijas īpašības," Materials Science and Applied Chemistry, vol. 29, pp. 63-68, Feb. 2014. https://doi.org/10.7250/msac.2013.022

[10] L. Dabare, R. Svinka, and V. Svinka, "Sorption of Inorganic Substances on the Porous Latvian Clay Ceramic," Latvian Journal of Chemistry, vol. 51, no. 4, Jan. 2012. https://doi.org/10.2478/v10161-012-0020-0

[11] R. Svinka, V. Svinka, L. Dabare, and O. Lescinskis, "Porous Clay Ceramic for Environmental Technologies," Advances in Science and Technology, vol. 91, pp. 88-93, Oct. 2014. https://doi.org/10.4028/www.scientific.net/ ast.91.88

[12] L. Dabare and R. Svinka, "Influence of thermal treatment and combustible additives on properties of Latvian clay ceramics pellets," Processing and Application of Ceramics, vol. 7, no. 4, pp. 175-180, 2013. https://doi. org/10.2298/pac1304175d

[13] R. Svinka, V. Svinka, and O. Lescinskis, "Possible modification of porous clay ceramic for environmental technologies," In Proc. of International Scientific Conference "Material Science and Applied Chemistry", 2016, pp.186-190.

[14] R. Švinka, V. Švinka, O. Leščinskis, and L. Dabare, "Keramiskā sorbenta iegūšanas pan̄ēmiens," LV Patent LV14870 B, 20 Aug., 2014.

[15] R. Svinka, V. Svinka, I. Pudze, and M. Damberga, "Clay Ceramic Pellets for Water Treatment / Mālu keramikas granulas ūdens apstrādei," Materials Science and Applied Chemistry, vol. 32, no. 1, pp. 39-44, Jan. 2015. https://doi.org/10.1515/msac-2015-0007

[16] L. Dabare and R. Svinka, "Characterization of porous ceramic pellets from Latvian clays," Chemija, vol. 25, no. 2, pp. 82-88, 2014.

[17] O. Muter, K. Potapova, V. Nikolajeva, Z. Petrina, T. Griba, A. Patmalnieks, R. Svinka, and V. Svinka, "Comparative study on Bacteria Colonization onto ceramic beads originated from two Devonian clay deposits in Latvia," Materials Science and Applied Chemistry, vol. 26, pp. 134-140, 2012. 
[18] A. Berzins, Z. Petrina, V. Nikolajeva, R. Svinka, V. Svinka, S. Strikauska, and O. Muter, "Characteristics of a Ceramic Carrier after Wastewater Treatment Process in the Model Column Cascade with Ethanol Addition," The Open Biotechnology Journal, vol. 9, no. 1, pp. 76-84, Jun. 2015. https://doi. org/10.2174/1874070701509010076

Ruta Švinka, Dr. sc. ing., asociētā profesore un Rīgas Tehniskās universitātes Materiālzinātnes un lietišksās k̦īmijas fakultātes Silikātu materiālu institūta vadošā pētniece. R. Švinka ir vairāk kā 100 publikāciju un 6 Latvijas patentu autore kīmijas inženierzinātnes silikātu materiālu un tehniskās keramikas nozarēs. R. Švinka ir Amerikas keramikas biedrības biedre, Latvijas Materiālu pētīšanas biedrības biedre un valdes locekle, LZP eksperte.

Telefons +37167615560

E-pasts: ruta.svinka@rtu.lv

ORCID: 0000-0002-9926-3956

Visvaldis Švinka, Dr. habil. sc. ing., asociētais profesors un Rīgas Tehniskās universitātes Materiālzinātnes un lietišķās k̦īmijas fakultātes Silikātu materiālu institūta vadošais pētnieks. V. Švinka ir vairāk kā 100 publikāciju un 17 patentu autors kīmijas inženierzinātnes silikātu materiālu un tehniskās keramikas nozarēs. V. Švinka ir Vācijas keramikas biedrības un Latvijas Materiālu pētīšanas biedrību biedrs, promocijas padomes P-02 loceklis un LZP eksperts.

Telefons +37167615560

E-pasts: visvaldis.svinka@rtu.lv

Ruta Švinka, Visvaldis Švinka.

\section{Building Ceramics, Expanded Clay, and Ceramic Sorbents.}

Keywords - ceramics, expanded clay, equilibrium moisture, thermal insulation, ceramic granules, sorbents.

Investigation and development of new building materials historically was one of base research fields in the Institute of Silicate Materials. These are ceramic materials and materials based on inorganic binders. These materials have both advantages and disadvantages. Properties of these materials, such as thermal conductivity, equilibrium humidity and mechanical properties, are analysed and compared. Properties and structure of ceramic materials produced from Latvian clays in the laboratory and industrially were compared. Influence of addition of some industrial waste on the properties of ceramic materials was described. A new technology for obtaining expanded clay pellets was developed. It is a one-step technology that makes it possible to extend the basis of raw materials for production of expanded clay pellets and to produce pellets with different properties depending on the possible practical use. Usefulness 
of different Latvian clay for the production of porous ceramic sorbents was investigated. Organic industrial waste was added to function as pore former. A treatment of ceramic surface by irradiation with accelerated electrons or coating with nanoparticles was analysed. An increase of sorption activity of ceramic pellets or usefulness for the photocatalytic decomposition of organic pollution was the goal of the aforementioned treatment.
Celtniecības keramika, keramzīts un keramiskie sorbenti 